\title{
Acrylamide-Based Pd-Nanoparticle Carriers as Smart Catalysts for the Suzuki-Miyaura Cross-Coupling of Amino Acids
}

\author{
Viktor Sabadasch ${ }^{\diamond a}$ \\ Steffen Dachwitz ${ }^{\diamond b}$ \\ Yvonne Hannappel ${ }^{a}$ \\ Thomas Hellweg*a,c \\ Norbert Sewald*b \\ a Department of Chemistry, Physical and Biophysical \\ Chemistry, Bielefeld University, Universitätsstraße 25, \\ 33615 Bielefeld, Germany \\ thomas.hellweg@uni-bielefeld.de \\ ${ }^{b}$ Department of Chemistry, Organic and Bioorganic \\ Chemistry, Bielefeld University, Universitätsstraße 25, \\ 33615 Bielefeld, Germany \\ norbert.sewald@uni-bielefeld.de \\ BINAS - Bielefeld Institute for Biophysics and Nanoscience, \\ Bielefeld University, Universitätsstraße 25, 33615 Bielefeld, \\ Germany \\ These authors contributed equally
}

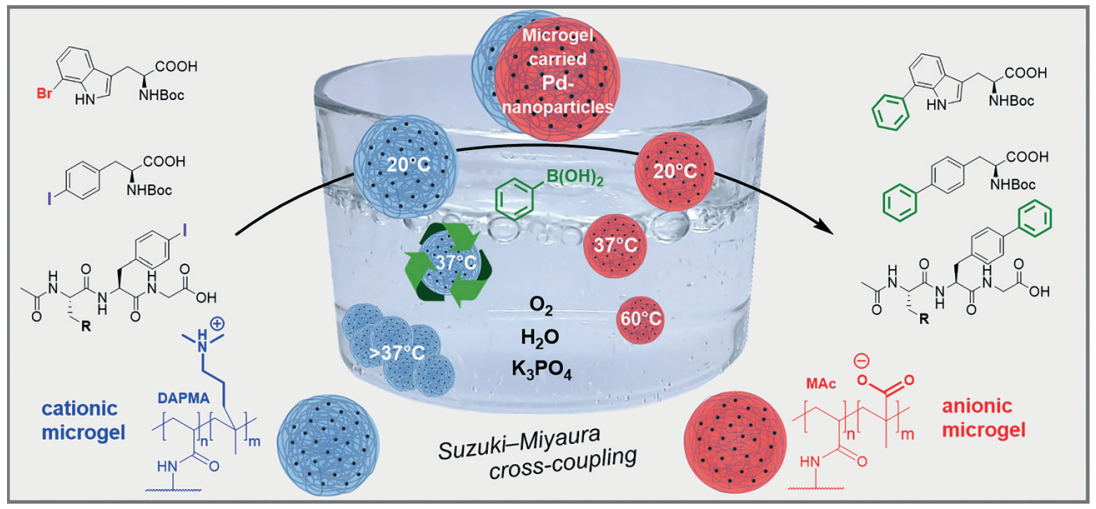

Received: 02.12.2021

Accepted after revision: 16.02 .2022

Published online: 25.02 .2022

DOI: 10.1055/a-1782-4224; Art ID: ss-2021-z0732-fa

License terms: CCO

(c) 2022. The Author(s). This is an open access article published by Thieme under the terms of the Creative Commons Attribution-NonDerivative-NonCommercial-License, permitting copying and reproduction so long as the original work is given appropriate credit. Contents may not be used for commercial purposes or adapted, remixed, transformed or built upon. (https://creativecommons.org/licenses/by-nc-nd/4.0/)

Abstract Polyacrylamide-based waterborne microgels were prepared with copolymerized carboxylic acid and tertiary amine moieties. The colloidal gels were loaded with palladium nanoparticles and utilized for the Suzuki-Miyaura cross-coupling of amino acids and peptides. The thermoresponsive properties of the prepared microgels were characterized by means of photon correlation spectroscopy (PCS) at solvent conditions of the catalytic reaction. The localization and morphology of the incorporated nanoparticles were characterized with transmission electron microscopy (TEM). Palladium-catalyzed Suzuki-Miyaura crosscoupling of $N^{\alpha}$-Boc-4-iodophenylalanine and $N^{\alpha}$-Boc-7-bromotryptophan with phenylboronic acid was carried out under ambient atmosphere in water at 20,37 , and $60^{\circ} \mathrm{C}$, respectively. The properties of the thermoresponsive microgel showed a strong influence on the reactivity and selectivity towards the respective substrate. For the amine containing microgels, a recyclability for up to four cycles without loss in activity could be realized. Furthermore, the systems showed good catalytic activity regarding Suzuki-Miyaura cross-coupling of halogenated amino acids in selected tri- and tetrapeptides.

Key words palladium catalysis, bioorganic chemistry, cross-coupling, amino acids, nanoparticles, polyacrylamide microgel, halogenated peptide, polymers

Bio-orthogonal catalysis under mild, aerobic conditions in water has become increasingly important in the search for more economical and ecologically friendly processes. In particular, the Suzuki cross-coupling is suitable for this purpose, since the required bases and aryl boronic acids are highly water soluble and tolerate most functional groups. ${ }^{1}$ Hence, the Suzuki-Miyaura reaction is an excellent method for (bio-)orthogonal late-stage functionalization of halogenated amino acids as well as complex biological molecules such as halogenated peptides or proteins. ${ }^{2,3}$ The arylation of a protein containing L-4-iodophenylalanine was reported by Chalker et al. using a Pd-pyrimidine precatalyst under aqueous conditions. ${ }^{4}$ Deb Roy et al. reported a SuzukiMiyaura reaction of unprotected halotryptophan in water and investigated the fluorescence properties of the obtained arylated tryptophans. ${ }^{5}$ However, unprotected halogenated amino acids required high temperatures. ${ }^{5}$ Willemse et al. investigated the influence of different amino acid side chains in halophenylalanine- and halotryptophancontaining dipeptides on the Suzuki-Miyaura reaction. ${ }^{6}$ The combination of biocatalytic halogenation and subsequent chemocatalytic arylation in a two-step, one-pot reaction without isolation of the halogenated species was reported independently by Latham et al. and Frese et al. ${ }^{7}$ Based on the fluorescence properties of arylated tryptophans, Schnepel et al. designed a high-throughput fluorescence assay for screening halogenases in directed evolution assays. ${ }^{8}$ The first arylations of biologically active macromolecules containing halotryptophan were reported by Sharma et al., describing an in vivo Suzuki-Miyaura cross-coupling on bromopacidamycin at $37^{\circ} \mathrm{C} .{ }^{9}$ Kemker et al. increased the stability and selectivity of cyclic RGD peptides using a Suzuki-Miyaura cross-coupling for fluorescence labelling or side chain to side chain cyclization. ${ }^{10}$

Catalysis by nanoparticles has recently attracted attention, since their catalytic activity does not require inert gas atmosphere. ${ }^{11}$ The direct use of nanoparticles is difficult to realize because agglomeration becomes a major problem when bulk metals are scaled down to nanoparticle size. Exceptionally, we were able to use ligand-free Pd-nanoparticles for the direct arylation of L-7-bromotryptophan and bromotryptophan containing peptides under ambient con- 

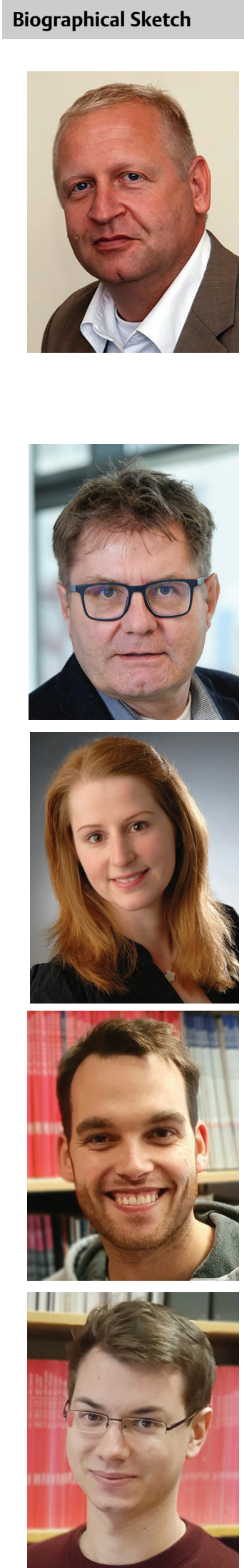

Thomas Hellweg currently works at the Faculty of Chemistry at Bielefeld University, where he is head of the Department of Physical and Biophysical Chemistry. He studied chemistry and physics at Bielefeld University where he obtained a doctoral degree in physical chemistry in 1995. Afterwards he spent about two years as a postdoc with Dominique Langevin and Didier Roux at Centre de Recherche Paul Pascal (CNRS) at Bordeaux. In 1998 he moved to the Technical University of Chemnitz where he worked at the physics department in the

Norbert Sewald was born in Munich in 1961 and studied chemistry at the Technical University of Munich. He obtained his $\mathrm{PhD}$ in organic chemistry ('New Strategies for the Synthesis of Trifluoromethyl Substituted Heterocycles, Amino Acids, and Hydroxy Acids') in the group of Prof. K. Burger. He was a postdoc in the group of Prof. J. E. Baldwin from 1991 to 1992 at the Dyson Perrins Laboratory,

Yvonne Hannappel studied polymer and colloidal chemistry at the University of Bayreuth and received her diploma in 2007. Afterwards she started her $\mathrm{PhD}$ at the same university

Steffen Dachwitz received his B.Sc degree in chemistry from the WWU Münster in 2015 and his M.Sc. degree in chemistry from Bielefeld University in 2018 specialized in bioorganic

Viktor Sabadasch studied chemistry at Bielefeld University, where he received his bachelor's degree in 2015 and his master's degree in 2018 in the group for materials research and liquids with Jens-Boie Suck. From Chemnitz he moved to TU Berlin where he worked in the group of Gerhard Findenegg and gained his habilitation for physical chemistry in 2005. In 2007 he accepted a call to Bayreuth University. In 2010 he accepted a call to Bielefeld University. He does research in Physical Chemistry and Materials Science with a focus on 'Soft Matter'. One of the current projects of the Hellweg group is 'Smart core-shell microgels as nanoparticle carriers for catalysis'. Another important current

Oxford University (Studies towards the Biomimetic Synthesis of Penicillin). In 1998 he finished his habilitation at the University of Leipzig. Since 1999 he has been Full Professor of Organic and Bioorganic Chemistry at Bielefeld University.

Norbert Sewald is coordinator of the Bilateral Yaoundé-Bielefeld Graduate School YaBiNaPA (2016-2025) and the Marie Skłodowska-Curie Training Net-

under the supervision of Prof. Thomas Hellweg, with her research focusing on the study of copolymer microgels and hydrogel nanoparticle hybrids. She successfully defended her thesis

synthesis. Since 2018 he has been working on his PhD studies in the Organic and Bioorganic Chemistry research group under the supervision of Prof. Dr. N. Sewald. He is particularly

Physical and Biophysical Chemistry group under the supervision of Prof. Thomas Hellweg. In 2018 he started his doctoral studies in the same group with project is the study of saponins and their interaction with lipid bilayers. Moreover, at present, confined microemulsions are also in the focus of the Hellweg group. The group uses mainly scattering experiments (light, $X$ rays, and neutrons) complemented by high-resolution imaging techniques such as cryogenic transmission electron microscopy (Cryo-TEM), scanning force microscopy, scanning electron microcopy (SEM), and different optical microscopy techniques.

works MAGICBULLET (20152018) and Magicbullet::reloaded (2020-2023). He is currently the President of the European Peptide Society.

His research interests comprise biocatalysis (enzymatic halogenation), bioconjugation (drug conjugates), peptide drugs, latestage diversification of peptides, peptidomimetics, and natural product chemistry.

in 2011 and is currently working as a senior scientist in the laboratory of Prof. Hellweg at Bielefeld University.

interested in transition-metalcatalyzed late-stage diversifications of indole-containing amino acids and peptides.

a research focus on the preparation and characterization of catalytically active metal-microgel hybrids. 
matrices may improve their colloidal stability and even their catalytic activity. Dumas et al. incorporated Pdnanoparticles into poly(D,L-lactide-glycolide)-block-poly(ethylene glycol) copolymer (PLGA-PEG-Pd-NPs). Using these assemblies as a catalyst in the Suzuki-Miyaura reaction of $N^{\alpha}$-Boc-L-4-iodophenylalanine provided up to $98 \%$ conversion in water at $37{ }^{\circ} \mathrm{C}$ after 18 h. ${ }^{12}$ Recently, Peramo et al. reported a self-assembling NHC-Pd-loaded calixarene as a catalyst for the arylation of Boc-protected L-4-iodophenylalanine, reaching $40 \%$ conversion after $3 \mathrm{~h}$ at $37^{\circ} \mathrm{C}$ in water. $^{13}$

Thermoresponsive microgels became promising candidates for the incorporation of nanoparticles because of their broad range of properties. ${ }^{14}$ Their characteristic feature is the responsiveness towards a change in temperature. When heated above the so-called volume phase transition temperature (VPTT) the highly hydrophilic polymer network collapses, shrinks in size, and expels water from its network. The mesh size of the polymer network decreases, and the gel becomes much more hydrophobic. One of the most studied microgel systems is based on poly- $N$-isopropylacrylamide (PNIPAM), which has a VPTT at about $32{ }^{\circ} \mathrm{C} .15,16$ Due to their unique properties, microgels have found applications in areas such as drug release, ${ }^{17}$ sensor materials ${ }^{18}$ or carriers for organocatalysts ${ }^{19}$ or catalytic nanoparticles. ${ }^{20}$ In the latter example, it is of particular interest that the activity of the embedded catalyst can be tuned with the degree of swelling of the polymer network. For gold nanoparticles embedded in a PNIPAM-based yolk-shell system, Wu et al. demonstrated that the reactivity of hydrophilic reactants decreases and that of hydrophobic reactants increases when the system was heated above the VPTT. ${ }^{21}$ AngiolettiUberti et al. were able to prove that the change in solubility observed by $\mathrm{Wu}$ et al. is mainly attributed to the change of solvation free-enthalpies at temperatures above the VPTT. ${ }^{22}$

Copolymerization of $\mathrm{pH}$-sensitive monomers such as amines or acids can greatly alter the thermoresponsive properties of microgels. ${ }^{23}$ In the case of acrylamide-based microgels copolymerized with methacrylic acid, the microgels show almost identical thermoresponsive properties in the protonated state of the acid as the system without methacrylic acid. ${ }^{24}$ Increasing the $\mathrm{pH}$ so that the methacrylic acid is completely deprotonated is accompanied by a large increase in particle size. This is due to the strong electrostatic repulsion of the carboxylate ions, which additionally impart a strong hydrophilic character to the network. The VPTT of the system was strongly broadened and shifted to much higher temperatures. Temperature-dependent catalysis of 4-nitrophenol on palladium nanoparticles embedded in that system showed that the catalytic activity strictly followed Arrhenius-like behavior and that the VPTT of the microgels had no effect on the reactivity of the embedded nanoparticles. ${ }^{24}$ By applying an acid-free shell to the microgels, the switchable property of the acrylamide material was restored. In contrast, another core-shell architecture loaded with silver nanoparticles also enabled an activating effect of the shells VPTT towards hydrophilic substrates. ${ }^{25}$

Another important feature of applying $\mathrm{pH}$-responsive moieties into microgel particles is that these moieties introduce defined charges into the microgel. These charges can be used to incorporate metal ions into the microgel at the location of the copolymer. By using this method, a defined localization of metal nanoparticles within the microgel can be achieved. ${ }^{14,24-26}$

In this work, four different palladium-loaded microgel systems are presented, namely poly- $N$ - $n$-propylacrylamide (PNNPAM) and PNIPAM systems, each copolymerized with either methacrylic acid (MAc) or $\mathrm{N}$-[3-(dimethylamino)propyl]methacrylamide (DAPMA). The comonomers MAc and DAPMA incorporate a carboxylic acid or a tertiary amine, respectively, into the network (Figure 1). The microgels were prepared in a surfactant-free precipitation polymerization approach. ${ }^{27}$ Potentiometric titration was used to determine the incorporation rates and apparent $\mathrm{p} K_{\mathrm{a}}$ values of the comonomers. The thermoresponsive properties of the systems were investigated by means of photon correlation spectroscopy (PCS). Localization and size of the incorporated palladium nanoparticles were investigated with transmission electron microscopy (TEM). Catalytic activity towards interesting substrates was investigated by performing Suzuki-Miyaura cross-coupling on phenylboronic acid with $N^{\alpha}$-Boc-4-iodophenylalanine and $N^{\alpha}$-Boc-7-bromotryptophan. Regarding $N^{\alpha}$-Boc-4-iodophenylalanine, the performance was tested in several recycling cycles. We also investigated the catalytic activity with different peptides containing either 7-bromotryptophan or 4-iodophenylalanine.

The determined amount and apparent $\mathrm{p} K_{\mathrm{a}}$ values of copolymerized MAc and DAPMA were analyzed by potentiometric titration as shown in Table 1.

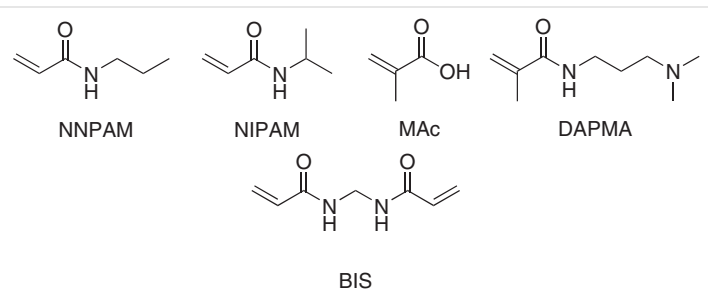

Figure 1 Structural formulae of the used acrylamide building blocks for PNNPAM and PNIPAM, the comonomers MAc and DAPMA and the crosslinker $N, N^{\prime}$-methylene-bisacrylamide (BIS)

While free MAc and DAPMA monomers have $\mathrm{p} K_{\mathrm{a}}$ values of 4.66 (acid) ${ }^{28}$ and 9.3 (ammonium), ${ }^{29}$ respectively, copolymerization into the polymer network shifts the $\mathrm{p} K_{\mathrm{a}}$ of MAc to higher values of 6.6 and 6.5, and that of DAPMA to lower values of 8.6 and 8.9 in the respective PNNPAM and PNIPAM microgels. This shift is commonly observed in pH-responsive polymeric material and is attributed to the polyelectrolyte effect. Neighboring pH-responsive moieties influence 
Table 1 Incorporated Amounts of Comonomer per Mass of Polymer Material $n_{\mathrm{co}} / m_{\text {poly }}$ and Apparent $\mathrm{p} K_{\mathrm{a}}$ Value of the Comonomer Determined via Potentiometric Titration

\begin{tabular}{lll}
\hline & $n_{\text {co }} / m_{\text {poly }}(\mathrm{mmol} / \mathrm{g})$ & $\mathrm{p} K_{\mathrm{a}}$ \\
\hline PNNPAM-co-MAC & $0.97 \pm 0.01$ & $6.5 \pm 0.1$ \\
PNIPAM-co-MAc & $0.71 \pm 0.02$ & $6.6 \pm 0.2$ \\
PNNPAM-co-DAPMA & $0.67 \pm 0.03$ & $8.6 \pm 0.2$ \\
PNIPAM-co-DAPMA & $0.79 \pm 0.02$ & $8.9 \pm 0.1$ \\
\hline
\end{tabular}

each other upon deprotonation, shifting their $\mathrm{p} K_{\mathrm{a}}$ towards weaker acids/bases with increasing degree of ionization. ${ }^{30}$ Comparing the incorporation rate of the comonomers, methacrylic acid is better incorporated in the slightly more hydrophobic acrylamide system PNNPAM, while the DAPMA system is better incorporated in the slightly more hydrophilic ${ }^{31}$ PNIPAM system.

We performed photon correlation spectroscopy (PCS) experiments to probe the temperature-dependent properties of the colloidal dispersed particles. The hydrodynamic radii of the PNNPAM and PNIPAM microgels copolymerized with methacrylic acid in a $\mathrm{K}_{3} \mathrm{PO}_{4}$ solution at a $\mathrm{pH}$ value of 12 are plotted against the temperature in Figure 2. The chosen $\mathrm{K}_{3} \mathrm{PO}_{4}$ solution and $\mathrm{pH}$ value corresponds to the requirements of the subsequent Suzuki-Miyaura crosscoupling reactions.

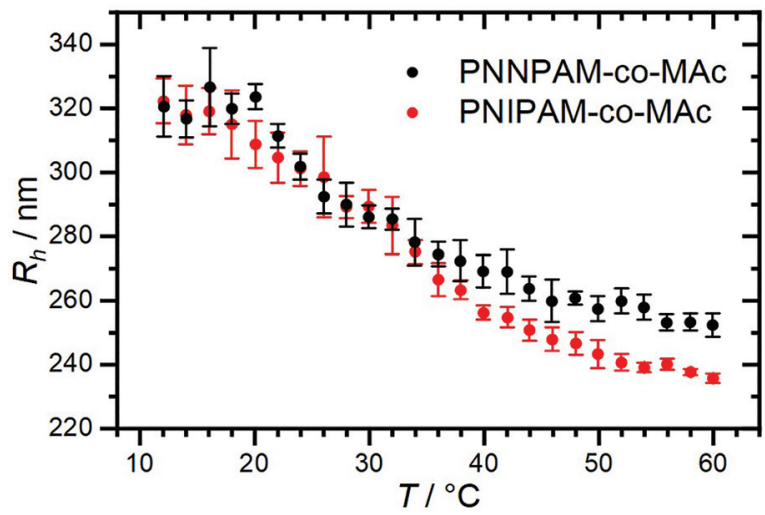

Figure 2 The hydrodynamic radii of the PNNPAM-CO-MAC and PNIPAM-co-MAc microgels plotted against the temperature. The measurements were performed in a $50 \mathrm{mM} \mathrm{K}_{3} \mathrm{PO}_{4}$ solution at pH 12 .

Since the apparent $\mathrm{p} K_{\mathrm{a}}$ values of the methacrylic acidcontaining systems are 6.6 and 6.5 , respectively (Table 1 ), a $\mathrm{pH}$ value of 12 induces a complete deprotonation of the methacrylic acid, leading to strong electrostatic repulsions of the carboxylates in the microgel..$^{32}$ At a temperature of $12{ }^{\circ} \mathrm{C}$, both systems are in their completely swollen state and have a hydrodynamic radius of about $320 \mathrm{~nm}$. When the temperature is increased, both systems show a steady decrease in size over the entire temperature range. The characteristic sharp VPTTs of homopolymer PNNPAM microgels at $22{ }^{\circ} \mathrm{C}^{33}$ and homopolymer PNIPAM microgels at $32{ }^{\circ} \mathrm{C}^{15}$ can no longer be clearly identified. The increased hydrophilicity and electrostatic repulsion, which result from the present carboxylates, shift the VPTT of the systems to far higher temperatures. At $60{ }^{\circ} \mathrm{C}$, the PNNPAM and PNIPAM systems show hydrodynamic radii of about 250 and $235 \mathrm{~nm}$, respectively. The PNIPAM system collapses to a greater extent than the PNNPAM system, which is attributed to the lower content of deprotonated hydrophilic carboxylates within the PNIPAM network (Table 1 ).

Temperature-dependent PCS measurements at a pH value of 12 were also performed for the PNNPAM-co-DAPMA and PNIPAM- co-DAPMA microgels (Figure 3). In contrast to MAc, DAPMA is an acrylamide-comonomer with a tertiary amine functionality. Its apparent $\mathrm{p} K_{\mathrm{a}}$ value is 8.6 or 8.9 in the PNNPAM-co-DAPMA or PNIPAM-co-DAPMA system, respectively. At a pH of 12 the amines are thus mostly deprotonated and no charges other than those of the initiator used, 2,2'-azobis-2-methylpropionamidine, are present in the microgel. In the fully swollen state at a temperature of $12{ }^{\circ} \mathrm{C}$, the PNNPAM system $(270 \mathrm{~nm})$ is about $30 \mathrm{~nm}$ larger than the PNIPAM system. Increasing the temperature leads to a VPTT of the PNNPAM system at about $26{ }^{\circ} \mathrm{C}$ and the PNIPAM system at about $32{ }^{\circ} \mathrm{C}$. Within the volume phase transition, a strong increase in $R_{\mathrm{h}}$ is observed. This increase is caused by strong interaction effects of the colloidal particles, which interfere with the independent diffusion of the particles. The dynamic light scattering data above the VPTT can thus no longer be evaluated. This observation is characteristic for amine-containing microgels. ${ }^{34}$ The effect of microgel interaction above the VPTT is very pronounced in the presented DAPMA microgels, indicating that the volume phase transition induces a strong shift of physicochemical properties of the particles.

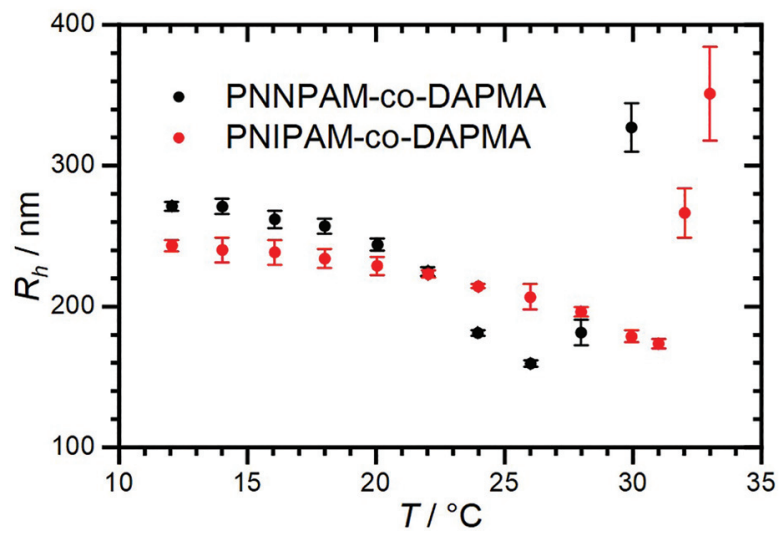

Figure 3 Hydrodynamic radius plotted against the temperature for the PNNPAM-Co-DAPMA and PNIPAM-co-DAPMA systems. Both systems were investigated in a $50 \mathrm{mM} \mathrm{K}_{3} \mathrm{PO}_{4}$ solution at $\mathrm{pH} 12$. Beyond the VPTT the particles start to interact, leading to an increase in the apparent hydrodynamic radius. 
The incorporation of palladium nanoparticles in the MAc and DAPMA microgels was performed with two different palladium complexes. Whereas the MAc systems were mixed with a $\left[\operatorname{Pd}\left(\mathrm{NH}_{3}\right)_{4}\right]^{2+}$ solution under basic conditions, the DAPMA-containing systems were mixed with anionic palladium chloride complexes at a low $\mathrm{pH}$ value. The aim was to use the deprotonated MAc as anchor points for the positive $\left[\mathrm{Pd}\left(\mathrm{NH}_{3}\right)_{4}\right]^{2+}$ complex and the protonated DAPMA moieties as anchors for the anionic palladium chloride complexes. Subsequent addition of sodium borohydride reduced the metal salts to the catalytically active Pd nanoparticles. Using this method, we were already able to load methacrylic acid containing systems with palladium nanoparticles. ${ }^{24}$ Loading of DAPMA-containing systems was previously demonstrated for PNIPAM-based gel particles by Seto et al. ${ }^{14}$ TEM images of the prepared microgel/Pd-hybrid microgels are shown in Figure 4 (top). The microgels copolymerized with methacrylic acid show similar loadings with nanoparticles. While the PNNPAM-co-MAc system incorporated nanoparticles with a size of $(8.7 \pm 0.8) \mathrm{nm}$ the PNIPAM-co-MAc system contains nanoparticles with a size of $(12.7 \pm 1.5) \mathrm{nm}$ (see the Supporting Information, Figure S1). In both cases, the localization seems to be in the center of the particle rather than in the outer part. Previous assumption of Hoare et al. state that MAc copolymerizes faster than NIPAM and is therefore more likely to be localized in the particle center. ${ }^{26}$ Although the images (Figure 4) are only two-dimensional views through completely dried microgels, localization in the particle center is likely.

The PNNPAM-co-MAc system shows a stronger microgel contrast than the PNIPAM system. This could be due to a higher content of crosslinkers in the microgel, resulting in a higher rigidity of the network, with the microgel drying in a more compact structure on the substrate. ${ }^{35}$

Nanoparticle incorporation in the DAPMA-containing systems shows significantly different results. In both cases (Figure 4, bottom) extremely small nanoparticles throughout the whole microgel were incorporated. In both DAPMA systems the nanoparticles with a size of $<3 \mathrm{~nm}$ are clearly separated, and no aggregation occurs. A quantitative size analysis of the palladium nanoparticles was not possible. Nevertheless, due to their very small size, the nanoparticles in the DAPMA systems yield a much larger surface-to-mass ratio than the nanoparticles incorporated in the MAc systems.

The thermoresponsive properties of the microgels were preserved after nanoparticle incorporation (see the Supporting Information, S2 and S3).

The catalytic activity of the embedded Pd-nanoparticles was investigated in a Suzuki-Miyaura cross-coupling of two different $N^{\alpha}$-Boc-protected halogenated amino acids, namely 4-iodophenylalanine (1) and 7-bromotryptophan (2), with phenylboronic acid (3, 2 equiv). The four microgel Pdnanoparticle hybrid systems were tested on a $10 \mathrm{~mm}$ scale
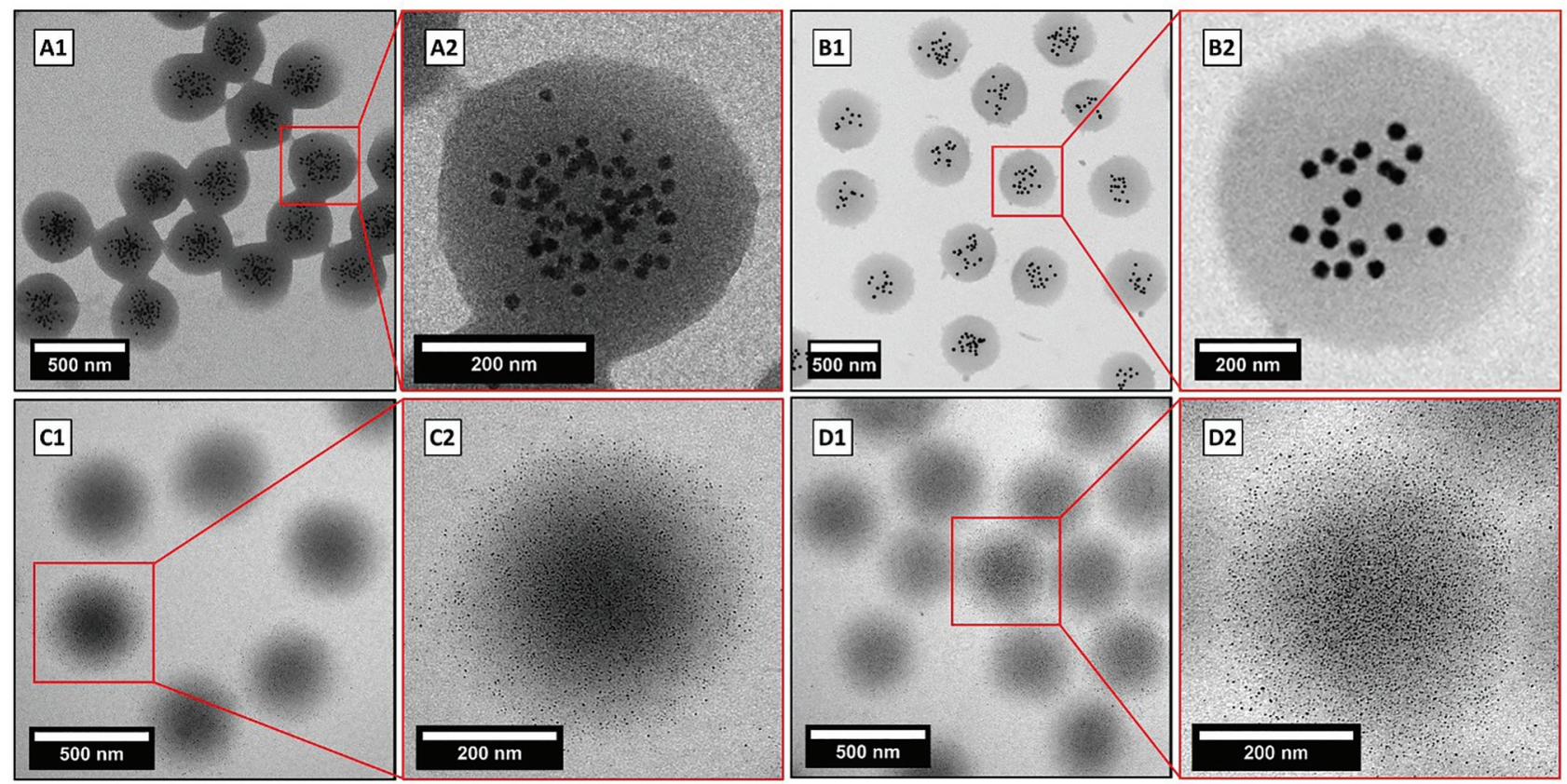

Figure 4 (A1) Image of PNNPAM-co-MAc microgels loaded with palladium nanoparticles. The mean nanoparticle radius was (8.7 \pm 0.8$) \mathrm{nm}$. (B1) TEM images of PNIPAM-co-Mac microgels loaded with $(12.7 \pm 1.5) \mathrm{nm}$ big nanoparticles. TEM image of PNNPAM-Co-DAPMA (C1) and PNIPAM-Co-DAPMA (D1) microgels decorated with palladium nanoparticles with a size of a few nanometers. (A2-D2): Zoom-in on a single microgel of the respective system. 
of the amino acid with $\mathrm{K}_{3} \mathrm{PO}_{4}$ ( 5 equiv) as base under aerobic and aqueous conditions at room temperature, $37{ }^{\circ} \mathrm{C}$ and $60{ }^{\circ} \mathrm{C}$, respectively. The progress of the reaction was monitored by reversed-phase high-performance liquid chromatography (RP-HPLC) (see Table 2 and Table 3 ). The palladium nanoparticles embedded in PNIPAM-co-MAc and PNIPAM-co-DAPMA microgels gave most promising results in the Suzuki-Miyaura coupling of $N^{\alpha}$-Boc-4-iodophenylalanine 1 , giving full conversion at $37^{\circ} \mathrm{C}$ after $24 \mathrm{~h}$ as well as reasonable conversions of 30 and $46 \%$ after $24 \mathrm{~h}$ at room temperature, respectively (Table 2, entries 2 and 4). Notably, the PNNPAM-co-MAc and PNIPAM-co-DAPMA systems show similar conversions at room temperature (entries 2 and 3), but at $37{ }^{\circ} \mathrm{C}$ the PNIPAM-co-MAc encapsulated nanoparticles give full conversion after $24 \mathrm{~h}$, while the PNNPAM-co-DAPMA system gave only $62 \%$. In the case of the PNNPAM-co-MAc system, conversion was increased from $6 \%$ at $20{ }^{\circ} \mathrm{C}$ to $51 \%$ at $37{ }^{\circ} \mathrm{C}$, making the MAc-containing microgels more favorable at elevated temperatures. All in all, for the Suzuki-Miyaura cross-coupling of iodophenylalanine (1), the cationic DAPMA systems show better catalytic activities at room temperature compared to the anionic MAc microgels, while the MAc microgel embedded nanoparticles show better reactivities at $37^{\circ} \mathrm{C}$ (for more detailed conversion as function of time see the Supporting Information, Figure S4-S6).

Due to the intense formation of microgel agglomerates of the DAPMA systems at 26 and $32{ }^{\circ} \mathrm{C}$ (see Figure 2), respectively, no reactions above $37^{\circ} \mathrm{C}$ were performed. Reusability is a major advantage of microgel carried nanoparticle catalysts. Hence, the recyclability of the four microgel

Table 2 Suzuki-Miyaura reaction of $N^{\alpha}$-Boc-4-iodophenylalanine 1 with Phenylboronic Acid 3 Catalyzed by Microgel Pd-Nanoparticle Hybrid Systems at Different Temperatures

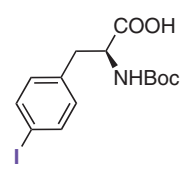

1

Entry Catalyst

\begin{tabular}{llcrc} 
Entry & Catalyst & \multicolumn{3}{c}{ Conversion (\%) } \\
& & $20{ }^{\circ} \mathrm{C}$ & $37{ }^{\circ} \mathrm{C}$ & $60{ }^{\circ} \mathrm{C}$ \\
\hline 1 & PNNPAM-co-MAC & 6 & 51 & 100 \\
2 & PNIPAM-co-MAC & 30 & 100 & $100^{\mathrm{c}}$ \\
3 & PNNPAM-Co-DAPMA & 31 & 62 & n.d. $^{d}$ \\
4 & PNIPAM-Co-DAPMA & 46 & 100 & n.d. $^{d}$
\end{tabular}

a Determined by HPLC $(220 \mathrm{~nm})$.

b For detailed conversion as function of time see the Supporting Information.

' Reaction was complete after two hours.

d Not determined. embedded Pd-nanoparticles was investigated by the reaction of iodophenylalanine (1) and phenylboronic acid (3) at $37^{\circ} \mathrm{C}$. Catalysis was performed over $48 \mathrm{~h}$, then the conversion was monitored by RP-HPLC at $220 \mathrm{~nm}$ and the reaction vessel was centrifuged at $10.000 \mathrm{rpm}$ for 10 minutes. The supernatant solution was discarded, and the remaining catalyst was resuspended in a freshly prepared solution of all reactants. This procedure was repeated until a loss in reactivity was observed (Figure 5).

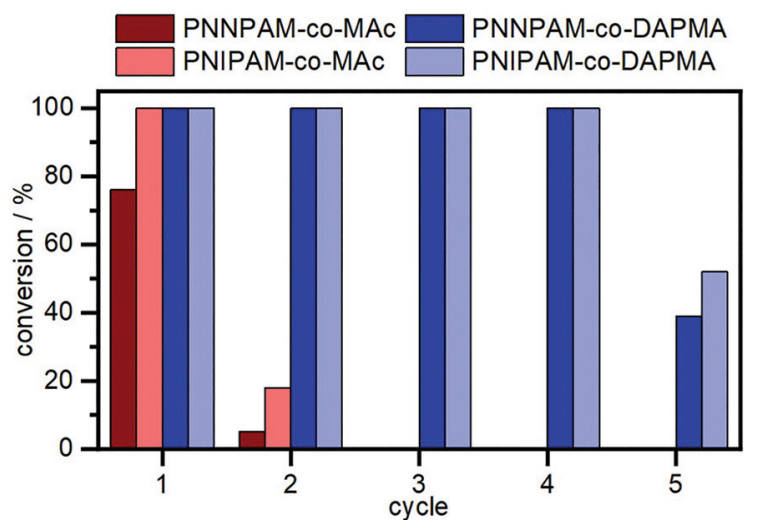

Figure 5 Activity of microgel embedded Pd-nanoparticle catalysts for Suzuki-Miyaura cross-coupling of $\mathrm{N}^{\alpha}$-Boc- 4 iodophenylalanine 1 with phenylboronic acid 3 at $37^{\circ} \mathrm{C}$ in different cycles of $48 \mathrm{~h}$ each

The MAc copolymer microgels showed almost no recyclability, giving 5 and 19\% in the second cycle after $48 \mathrm{~h}$, respectively. The DAPMA systems showed no observable loss in reactivity before the fifth cycle, still providing 39 and $52 \%$ conversion after four recycles. In comparison, the PNIPAM system seems to be slightly better to recycle than the PNNPAM system. The TEM images after the cycle in which reactivity is lost (cycle two for co-MAc and cycle five for co-DAPMA) show that the microgels are soaked with non-volatile material, which is presumably product, in the case of the MAc-containing systems (see the Supporting Information, Figure S7). This likely causes the microgel network to become clogged and no new reactant can reach the catalyst. The DAPMA systems, despite their now undefined outer region, appear to be unaffected by the catalytic cycles. As can be seen in the TEM micrographs shown in the Supporting Information, the nanoparticles generally retained their morphology and size after use in the reaction (see the Supporting Information, Figure S7).

Besides the very reactive Boc-iodophenylalanine $\mathbf{1}$, the less reactive amino acid $N^{\alpha}$-Boc-7-bromotryptophan (2) was chosen as an additional starting material for SuzukiMiyaura cross-coupling. Due to the lower reactivity of bromoarenes and the high electron density of the indole moiety of tryptophan, it represents a less reactive substrate in Suzuki-Miyaura couplings, leading to lower conversions compared to iodophenylalanine (1). However, both PNIPAM systems again gave higher conversion (30\% and $29 \%$ ) into 
$N^{\alpha}$-Boc-7-phenyltryptophan (5) within 24 h at $37{ }^{\circ} \mathrm{C}$ (Table 3 , entries 2 and 4). In comparison, ligand-free Pd-nanoparticles give full conversion after $2 \mathrm{~h}$ at $40^{\circ} \mathrm{C}$. $^{3}$

Table 3 Suzuki-Miyaura Reaction of $N^{\alpha}$-Boc-7-bromotryptophan (2) with Phenylboronic Acid $\mathbf{3}$ Catalyzed by Microgel Pd-Nanoparticle Hybrid Systems at Different Temperatures

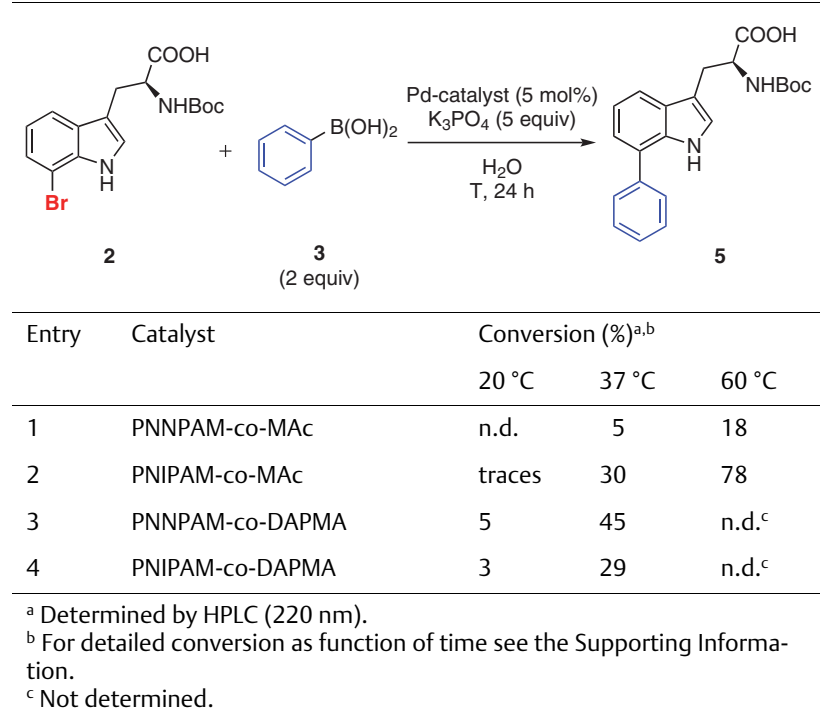

Notably, the PNNPAM-co-DAPMA microgel incorporated nanoparticles gave $45 \%$ conversion after $24 \mathrm{~h}$ at $37^{\circ} \mathrm{C}$ (Table 3 , entry 3 ) while PNNPAM-co-MAc nanoparticles only gave $5 \%$ conversion (entry 1 ). Comparing these results with the conversions of $N^{\alpha}$-Boc-4-iodophenylalanine (1), in which both mentioned catalysts showed almost the same reactivity, giving $51 \%$ (Table 2 , entry 1 ) and $62 \%$ (Table 2 , entry 3 ), respectively; this shows a major difference in the substrate selectivity of the anionic and cationic microgel systems. At room temperature, all catalytic microgels gave only low conversions of $N^{\alpha}$-Boc-7-bromotryptophan (2) with maximum of $5 \%$ in $24 \mathrm{~h}$. Due to the intense formation of microgel agglomerates of the DAPMA systems at 26 and $32{ }^{\circ} \mathrm{C}$ (Figure 3), respectively, no reactions above $37{ }^{\circ} \mathrm{C}$ were performed (for more detailed conversion as function of time diagrams see the Supporting Information, Figure S8-S10). During all reactions with the MAc microgels at $60{ }^{\circ} \mathrm{C}$, byproducts such as homo-coupled phenylboronic acid $(<5 \%)$ and cleavage of Boc protecting groups (13\% in $24 \mathrm{~h}$ ) were observed via RP-HPLC, independent of the nature of the substrate and catalyst.

A remarkable shift in solubility of the reactants above the VPTT was observed for the PNNPAM systems. While the PNNPAM-co-MAc system showed only a conversion of $5 \%$ at $37^{\circ} \mathrm{C}$, the PNNPAM-co-DAPMA system showed an increase from only $5 \%$ conversion at $20^{\circ} \mathrm{C}$ to $45 \%$ at $37^{\circ} \mathrm{C}$. This strong increase in reactivity can be attributed to the strong influence of the volume phase transition of the particle (see Figure 3). Upon heating the PNNPAM-co-DAPMA system above its VPTT at $26{ }^{\circ} \mathrm{C}$ it became more hydrophobic and the similarly hydrophobic $N^{\alpha}$-Boc-7-bromotryptophan was more soluble in the network, leading to an increased catalytic activity of the embedded palladium nanoparticles.

To finally demonstrate the usability of microgel carried Pd-nanoparticles as catalysts for complex natural compounds such as peptides under environmental conditions, three different 4 -iodophenylalanine containing tripeptides

Table 4 Suzuki-Miyaura Reaction of Three 4-lodophenylalanine-Containing Tripeptides with Phenylboronic Acid 3 Catalyzed by Microgel Pd-Nanoparticle Hybrid Systems

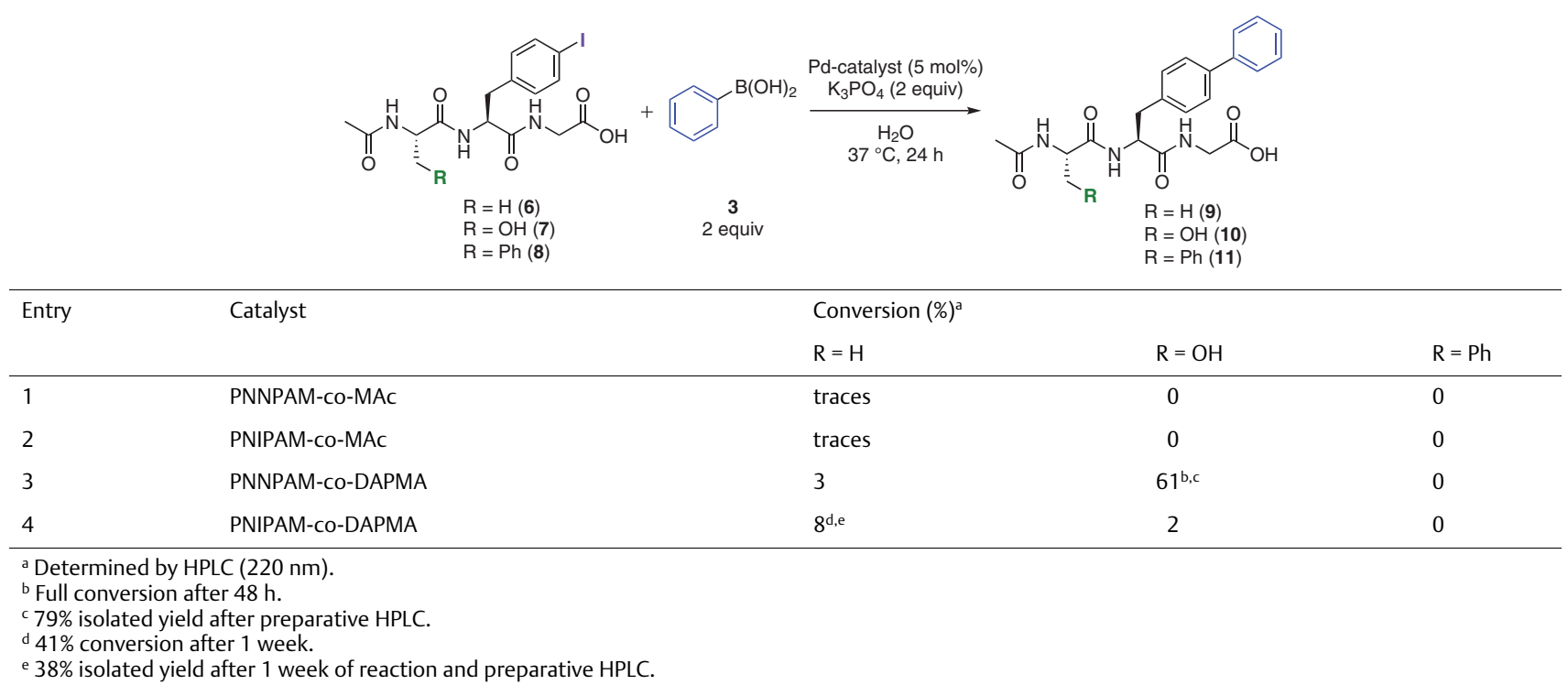


were prepared as substrates for a Suzuki-Miyaura coupling. The cross-coupling was performed under ambient, aerobic conditions at $37{ }^{\circ} \mathrm{C}$ in water to prevent degradation of the peptides (Table 4).

Tripeptide (8), which contains an additional phenylalanine to increase the lipophilicity of the tripeptide, showed no conversion with any catalyst under the chosen reaction conditions, and only substrate was recovered. Using the MAc microgel embedded Pd-nanoparticles only traces of $\mathbf{9}$ could be observed by HPLC. Surprisingly, DAPMA-containing microgel systems showed contrary substrate selectivity. The PNNPAM-Co-DAPMA embedded nanoparticles gave 3\% conversion of $\mathbf{9}$ after 24 h but a 20 -fold higher conversion (61\%) of the slightly more polar substrate 7 to give $\mathbf{1 0}$ (Table 4 , entry 3). PNIPAM-Co-DAPMA embedded nanoparticles showed a threefold higher conversion (8\%) within 24 h of 6 to give 9 compared to $2 \%$ conversion of 7 (entry 4 ).

Encouraged by these results, 7-bromotryptophan-containing tripeptide and tetrapeptide were synthesized as substrates for Suzuki-Miyaura cross-coupling (Table 5). Since we recently observed a drastic acceleration effect by methionine in the peptide chain on the reactivity of bromotryptophan-containing peptides in Pd-nanoparticle catalyzed Suzuki-Miyaura cross couplings, these two peptides were prepared with a methionine at the $\mathrm{N}$-terminus. ${ }^{7}$

To reach sufficient solubility of the tetrapeptide $\mathbf{1 3}$ in water, aspartic acid was also introduced into the peptide se- quence. According to the results of the screenings before, only DAPMA copolymerized microgel systems were tested. In case of the bromotryptophan-containing peptides PNIPAM-co-DAPMA embedded Pd-nanoparticles gave better conversions of $21 \%$ of $\mathbf{1 2}$ and $17 \%$ of $\mathbf{1 3}$ compared to the PNNPAM system which gave only $4 \%$ maximum conversion. However, the tripeptide was the better accepted substrate by both systems.

In conclusion, polyacrylamide based microgels containing carboxylic acid and tertiary amine moieties loaded with Pd-nanoparticles have been identified as suitable catalysts for the bio-orthogonal Suzuki-Miyaura cross-coupling of halogenated amino acids under mild, aerobic, and aqueous conditions between ambient temperature and $60{ }^{\circ} \mathrm{C}$. The thermoresponsive properties of the presented microgel systems were characterized by means of temperature-dependent PCS measurements at analogous conditions to the catalysis at elevated $\mathrm{pH}$ value. While the MAc-containing systems showed a steady volume phase transition over the whole temperature range and full colloidal stability, a sharp change in properties was observed for the amine-containing microgels. At the respective VPTT of the used acrylamide, strong aggregation effects were observed, indicating a strong shift in hydrophobicity within the microgel particle. The palladium-loaded microgels were characterized via TEM, revealing that the MAc systems incorporate the nanoparticles with sizes between $(8.7 \pm 0.8) \mathrm{nm}$ and $(12.7 \pm$

Table 5 Suzuki-Miyaura Reaction of 7-Bromotryptophan-Containing Tripeptide $\mathbf{1 2}$ or Tetrapeptide $\mathbf{1 3}$ with Phenylboronic Acid 3 Catalyzed by Microgel Pd-Nanoparticle Hybrid Systems

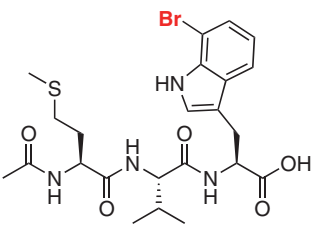

12

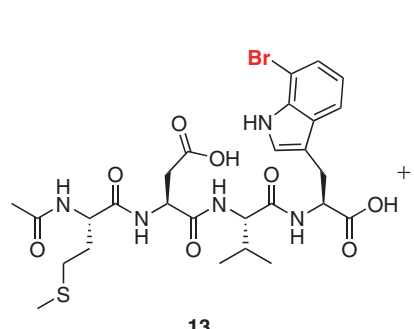

13

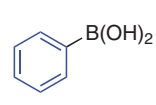

3 (2 equiv)

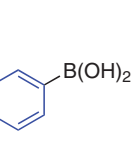

3

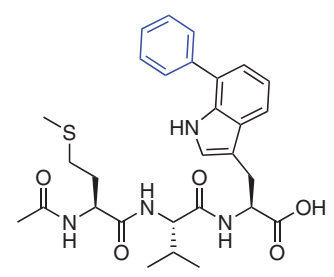

14

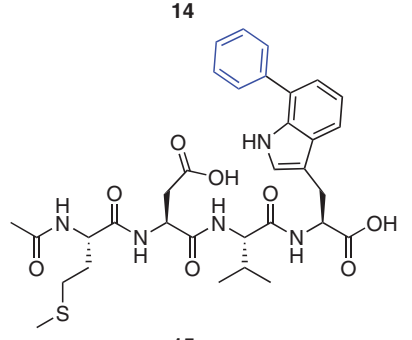

15

\begin{tabular}{llcc}
\hline Entry & Catalyst & Conversion (\%) $^{\text {a }}$ & $\mathbf{1 2}$ \\
\hline 1 & & 4 & traces \\
2 & PNNPAM-co-DAPMA & 21 & 17 \\
\hline
\end{tabular}

a Determined by HPLC (220 nm). 
1.5) $\mathrm{nm}$, and locate probably towards the particle center. The amine systems incorporated nanoparticles with only a few nanometers throughout the whole microgel spheres. Despite their very small size, no visible aggregation of the nanoparticles could be observed. The subsequent SuzukiMiyaura cross-coupling of 4-iodophenylalanine and 7-bromotryptophan with phenylboronic acid revealed that hydrophilic MAc-containing systems are more suitable for the catalysis of the coupling of 4-iodophenylanaline, DAPMAcontaining systems showed superior activity in the catalysis of 7-bromotryptophan coupling. The PNNPAM-coDAPMA, with its pronounced volume phase transition, showed superior reactivity with respect to the conversion of the 7-bromotryptophan, when heated above the VPTT. This emphasizes that the thermoresponsivity adds an additional degree of freedom to tune the catalytic activity of embedded nanoparticles.

Regarding the catalysis of 4-iodophenylalanine on the DAPMA systems, a recycling in up to four cycles was possible without loss in activity. The DAPMA-containing systems were further used to catalyze the coupling of 4-iodophenylalanine- or 7-bromotryptophan-containing tripeptides and tetrapeptides, showing that the choice of acrylamide is decisive for the selectivity.

$N$-Isopropylacrylamide (NIPAM) was recrystallized from $n$-hexane. $N$ $n$-Propylacrylamide (NNPAM) was prepared by a Schotten-Baumann synthesis as described by Hirano et al. ${ }^{36}$ Unless otherwise stated, the chemicals used were obtained from commercial suppliers with analytical grade.

\section{Microgel Synthesis}

The microgels were synthesized by precipitation polymerization. The respective acrylamide NIPAM or NNPAM (38.51 mmol), BIS (1.92 mmol, $5 \mathrm{~mol} \%$ ), and respective comonomer MAc or DAPMA (3.85 $\mathrm{mmol}, 10 \mathrm{~mol} \%$ ) were dissolved in $490 \mathrm{~mL}$ water. The mixture was purged with nitrogen and heated to $70{ }^{\circ} \mathrm{C}$ under constant stirring for 2 hours. The polymerization was initiated by the addition of ammonium persulfate ( $1.36 \mathrm{mmol}, 3.5 \mathrm{~mol} \%$ ) for the MAc-containing systems or 2,2'-azobis-2-methylpropionamidine (1.36 mmol, $3.5 \mathrm{~mol} \%$ ) for the DAPMA containing systems dissolved in $10 \mathrm{~mL}$ of purified water. The reaction proceeded for $4 \mathrm{~h}$ under constant stirring at $70^{\circ} \mathrm{C}$. Afterwards the reaction solution was cooled to room temperature and stirred overnight. The microgel was purified by five consecutive centrifugation, decantation and redispersion cycles with purified water. The PNNPAM-co-DAPMA system was synthesized on a reduced scale with $150 \mathrm{~mL}$ water.

\section{Nanoparticle Loading}

For the loading of the PNNPAM-co-MAc and PNIPAM-co-MAc systems, a reaction solution $(45 \mathrm{~mL})$ containing the respective microgel (100 mg anhydrous mass of microgel) and a palladium solution ( $\mathrm{PdCl}_{2} 20$ $\mathrm{mM}, \mathrm{NH}_{3} 800 \mathrm{mM}$ ), which was in a fivefold excess to the incorporated amount of MAc (see Table 1) was prepared. After stirring with a magnetic stirrer for one hour and degassing with nitrogen under ice bath cooling, a sodium borohydride solution $(5 \mathrm{~mL})$ was added in fourfold excess, in respect to the $\mathrm{Pd}^{2+}$ concentration. After stirring overnight, the suspension was filled into a dialysis tube (Spectra/Por Biotech CE Tubing $1000 \mathrm{kDa}$, Repligen, Waltham, MA, USA) and dialyzed against water in a beaker with a volume of $5 \mathrm{~L}$. The suspension was dialyzed for 36 hours. Within this time, the water was replaced four times. The PNNPAM-Co-DAPMA and PNIPAM-Co-DAPMA systems were loaded analogously. Alternatively, a $\mathrm{PdCl}_{2}$ solution $(20 \mathrm{mM})$ with $\mathrm{HCl}(40$ $\mathrm{mM}$ ) instead of $\mathrm{NH}_{3}$ was used. The amount of palladium added corresponded to half the amount of DAPMA groups contained in the respective microgel (see Table 1 ).

\section{Nanoparticle Characterization}

The samples were prepared on carbon-coated copper grids (ECF200$\mathrm{Cu}, 200$ mesh, Science Services, Munich, Germany). The grids were pre-treated in a plasma cleaner (Diener Electronics, Ebhausen, Germany) with argon. The sample $(3 \mu \mathrm{L})$ was applied onto the grids and after a sedimentation time of one minute, the excess suspension was removed with a filter paper. The prepared grids were analyzed with a JEOL JEM-2200FS electron microscope (JEOL, Freising, Germany) with a cold field emission electron gun and an applied acceleration voltage of $200 \mathrm{kV}$. A bottom-mounted Gatan OneView camera (Gatan, Pleasanton, CA, USA) was used for digital recording. The images were processed with the image-processing system Digital Micrograph GMS3 (Gatan, Pleasanton, CA, USA) and the image editing software ImageJ. ${ }^{37}$

The incorporated palladium mass relative to microgel/nanoparticlehybrid suspension was determined by atom absorption spectroscopy (see the Supporting Information, Table S1) by Mikroanalytisches Laboratorium Kolbe (Oberhausen, Germany).

\section{Titration}

A weighed amount of the respective microgel was dispersed with water and acidified with hydrochloric acid to a $\mathrm{pH}<3$. The suspension was then titrated against sodium hydroxide $(0.1 \mathrm{M})$ at a temperature of $(4 \pm 1)^{\circ} \mathrm{C}$ with a Metrohm 905 automatic titrator (Metrohm, Filderstadt, Germany). The sodium hydroxide was added in increments of $6 \mu \mathrm{L}$ every $5 \mathrm{~s}$. The half equivalence point between the neutralization points of the excess hydrochloric acid and the comonomer was taken as apparent $\mathrm{p} K_{\mathrm{a}}$ value.

\section{Photon Correlation Spectroscopy (PCS)}

Highly diluted microgel suspensions $(<0.002 \mathrm{wt} \%)$ were prepared in a $\mathrm{K}_{3} \mathrm{PO}_{4}$ solution ( $\mathrm{pH} 12,50 \mathrm{mM}$ ) and investigated in a self-build fixedangle PCS setup equipped with a HeNe-Laser (HN210L, Thorlabs Inc., Newton, NJ, USA) and a multiple- $\tau$ correlator (ALV-6010, ALV GmbH, Langen, Germany). The scattered light was detected at an angle of $45^{\circ}$ with a single-photon detector (ALV/SO-SIPD, ALV GmbH, Langen, Germany). The sample was placed in a thermostated index matching decalin bath. The equilibration time at every temperature was $1500 \mathrm{~s}$. At each temperature the sample was measured five times for a duration of $200 \mathrm{~s}$ each. The data were analyzed with a second-order cumulant fit. ${ }^{38}$ The obtained relaxation rates were used to calculate the translational diffusion coefficient $D_{\mathrm{T}}$ according to Equation 1 .

$$
\Gamma=D_{\top} \cdot q^{2}
$$

Equation 1

with $q$ being the magnitude of the scattering vector. The hydrodynamic radius $R_{\mathrm{h}}$ can be calculated according to the Stokes-Einstein equation (Equation 2): 
$D_{\top}=\frac{\mathrm{k}_{\mathrm{b}} \cdot T}{6 \pi \eta R_{\mathrm{h}}}$

Equation 2

with the Boltzmann constant $\mathrm{k}_{\mathrm{b}}$, the temperature $T$, and the solvent viscosity $\eta$.

\begin{abstract}
Analytical HPLC
Analytical HPLC was performed with a Shimadzu NexeraXR 20A System (Shimadzu, Kyoto, Japan) with autosampler, degasser, diode array detector and a Luna C18 column (Phenomenex, Torrance, CA, USA) $(2.9 \mu \mathrm{m}, 50 \times 2.1 \mathrm{~mm})$ with a gradient (in $5.5 \mathrm{~min}$ from $5 \% \mathrm{~B}$ to $95 \% \mathrm{~B}$, $0.5 \mathrm{~min} 95 \% \mathrm{~B}$ and back to $5 \% \mathrm{~B}$ in $3 \mathrm{~min}$, total run time $9 \mathrm{~min}$ ) at a flow rate of $650 \mu \mathrm{L} / \mathrm{min}$ and column oven temperature of $40{ }^{\circ} \mathrm{C}$. HPLC solvent A consisted of $99.9 \%$ water with $0.1 \%$ TFA, solvent B of $99.9 \%$ acetonitrile with $0.1 \%$ TFA.
\end{abstract}

\section{LC-MS}

Analytical LC-MS was performed with an Agilent 6220 TOF-MS (Agilent, Santa Clara, CA, USA) with a Dual ESI-source, 1200 HPLC system with autosampler, degasser, binary pump, diode array detector and a Phenomenex Luna C18 column $(2.9 \mu \mathrm{m}, 50 \times 2.1 \mathrm{~mm})$ with a gradient (in $11 \mathrm{~min}$ from $0 \% \mathrm{~B}$ to $98 \% \mathrm{~B}$, back to $0 \% \mathrm{~B}$ in $0.5 \mathrm{~min}$, total run time $15 \mathrm{~min}$ ) at a flow rate of $300 \mu \mathrm{L} / \mathrm{min}$ and column oven temperature of $40{ }^{\circ} \mathrm{C}$. HPLC solvent A consists of $94.9 \%$ water, $5 \%$ acetonitrile with $0.1 \%$ formic acid, solvent B of $5 \%$ water, $94.9 \%$ acetonitrile with $0.1 \%$ formic acid. ESI mass spectra were recorded after sample injection in extended dynamic range mode equipped with a Dual-ESI source, operating with a spray voltage of $2.5 \mathrm{kV}$.

\section{NMR Analysis}

NMR spectra were recorded with a Bruker Avance III $500 \mathrm{HD}\left({ }^{1} \mathrm{H}: 500\right.$ $\left.\mathrm{MHz},{ }^{13} \mathrm{C}: 126 \mathrm{MHz}\right)$ or Avance $600\left({ }^{1} \mathrm{H}: 600 \mathrm{MHz},{ }^{13} \mathrm{C}: 151 \mathrm{MHz}\right)$. Chemical shifts $\delta$ [ppm] are reported relative to residual solvent signals (DMSO- $d_{6},{ }^{1} \mathrm{H}: 2.50 \mathrm{ppm},{ }^{13} \mathrm{C}$ : $39.5 \mathrm{ppm}$ ). 2D spectra (COSY, HMQC, HMBC) spectra were used for signal assignment.

\section{Solid-Phase Peptide Synthesis; General Procedure}

All peptides were synthesized on 2-chlorotrityl chloride resin using the Fmoc/t'Bu-strategy. In case of the 4-iodophenylalanine-containing tripeptides, the resin was loaded with Fmoc-Gly-OH (4 equiv) and DIEA (8 equiv) in DCM at room temperature, shaken for 2 hours and remaining binding sites were capped by adding $\mathrm{MeOH}$ ( 15 equiv). The solution was filtrated, and the resin was thoroughly washed with DCM $(5 \times 1 \mathrm{~min})$. Fmoc-deprotection was performed by addition of $20 \%$ piperidine and $100 \mathrm{~mm} \mathrm{HOBt}$ in DMF to the resin and shaking for 15 minutes at room temperature; this procedure was repeated once. After deprotection, the resin was washed with $\operatorname{DMF}(5 \times 1 \mathrm{~min})$. Natural Fmoc-protected amino acids were coupled to the $N^{\alpha}$-deprotected peptide by addition of a mixture of amino acid ( 4 equiv), TBTU (4 equiv) and DIEA (8 equiv) in DMF to the resin and shaking for 2 hours at room temperature. After coupling, the resin was washed with DMF $(5 \times 1 \mathrm{~min})$ and and MTBE $(3 \times 1 \mathrm{~min})$ and dried in vacuo. Full conversion was verified by the Kaiser test. Fmoc-4-iodo-L-phenylalanine or Fmoc-7-bromo-L-tryptophan (1.2 equiv) was coupled to the $N^{\alpha}$ deprotected peptide on resin with HATU (1.2 equiv) and DIEA (2.4 equiv) in DMF at room temperature for 6 hours. Full conversion was verified by a test cleavage and analytical LC-MS. Before final cleavage, the peptide was $\mathrm{N}$-acetylated by addition of a solution of acetic anhydride ( 10 equiv) and pyridine ( 10 equiv) in DMF to the resin. Cleavage and side chain deprotection were performed by addition of a mixture of TFA $/ \mathrm{H}_{2} \mathrm{O} / \mathrm{TIS}(95: 2.5: 2.5)$ to the resin $(2 \times 1.5 \mathrm{~h})$ followed by peptide precipitation overnight in MTBE at $-20^{\circ} \mathrm{C}$. In case of methionine-containing peptides, a cleavage cocktail consisting of TFA/thioanisole/EDT/anisole (90:5:3:2) was used for peptide cleavage $(2 \times 1.5 \mathrm{~h})$ followed by peptide precipitation overnight in MTBE at $-20{ }^{\circ} \mathrm{C}$. This mixture was spun down $\left(4000 \mathrm{rpm} ; 4^{\circ} \mathrm{C} ; 5 \mathrm{~min}\right)$, the MTBE layer discarded, and the residue was dissolved in water and freeze dried. All peptides were purified by RP-HPLC.

\section{Suzuki-Miyaura Cross Coupling; General Procedure}

Cross-couplings were performed on benchtop. Aryl halide ( $5 \mu \mathrm{mol}$, 1.0 equiv) and boronic acid (2.0 equiv) were placed in a flask equipped with a stirring bar. $\mathrm{K}_{3} \mathrm{PO}_{4}$ (5.0 equiv) dissolved in water (500 $\mathrm{mm}, 50 \mu \mathrm{L})$ and water $(200 \mu \mathrm{L})$ were added to give a final aryl halide concentration of $10 \mathrm{~mm}$. The vessel was heated to the desired reaction temperature and the microgel/Pd-nanoparticle hybrids dissolved in water ( $250 \mu \mathrm{L}, 1 \mathrm{~mm}, 5 \mathrm{~mol} \%$ ) were added. The progress of the reaction was monitored by RP-HPLC at $220 \mathrm{~nm}$. After completion, the Pdnanoparticles were removed by centrifugation $(10.000 \mathrm{rpm}, 10 \mathrm{~min})$ and the reaction mixture was directly purified by preparative RPHPLC.

\section{Ac-Ala-Phe(4-I)-Gly-OH (6)}

Synthesized by solid-phase peptide synthesis (SPPS) on a 2 chlorotrityl resin on a $0.1 \mathrm{mmol}$ scale. The product $\mathbf{6}$ was isolated after reversed phase HPLC purification.

Yield: $9.9 \mathrm{mg}$ (22 $\mu \mathrm{mol}, 22 \%)$; colorless solid.

${ }^{1} \mathrm{H}$ NMR $\left(500 \mathrm{MHz}\right.$, DMSO- $d_{6}$ ): $\delta=12.59$ (br s, $\left.1 \mathrm{H}, \mathrm{COOH}\right), 8.30\left(\mathrm{t},{ }^{3} \mathrm{~J}=\right.$ $\left.5.9 \mathrm{~Hz}, 1 \mathrm{H}, \mathrm{CONH}^{\mathrm{Gly}}\right), 7.96$ (d, $\left.{ }^{3} \mathrm{~J}=7.3 \mathrm{~Hz}, 1 \mathrm{H}, \mathrm{CONH}^{\mathrm{Ala}}\right), 7.88$ (d, ${ }^{3} \mathrm{~J}=8.4$ $\left.\mathrm{Hz}, 1 \mathrm{H}, \mathrm{CONH}^{\text {Phe(4-I) }}\right), 7.58\left(\mathrm{~d},{ }^{3} \mathrm{~J}=8.2 \mathrm{~Hz}, 2 \mathrm{H}, \mathrm{C} 3-H\right), 7.04\left(\mathrm{~d},{ }^{3} \mathrm{~J}=8.2\right.$ $\mathrm{Hz}, 2 \mathrm{H}, \mathrm{C} 2-\mathrm{H}$ ), 4.49 (ddd, ${ }^{3} \mathrm{~J}=9.3 \mathrm{~Hz},{ }^{3} \mathrm{~J}=8.2 \mathrm{~Hz},{ }^{3} \mathrm{~J}=4.5 \mathrm{~Hz}, 1 \mathrm{H}, \mathrm{C} \alpha-$ $\left.H^{\text {Phe(4-I) }}\right), 4.25\left(\mathrm{dq},{ }^{3} J=7.9 \mathrm{~Hz},{ }^{3} \mathrm{~J}=7.2 \mathrm{~Hz}, 1 \mathrm{H}, \mathrm{C} \alpha-H^{\text {Ala }}\right), 3.86-3.69(\mathrm{~m}, 2$ $\left.\mathrm{H}, \mathrm{C} \alpha-H^{\mathrm{Gly}}\right), 2.99$ (dd, $\left.{ }^{2} \mathrm{~J}=13.8 \mathrm{~Hz},{ }^{3} \mathrm{~J}=4.5 \mathrm{~Hz}, 1 \mathrm{H}, \mathrm{C} \beta-H^{\text {Phe(4-I) }}\right), 2.75$ (dd, $\left.{ }^{2} J=13.9 \mathrm{~Hz},{ }^{3} J=9.3 \mathrm{~Hz}, 1 \mathrm{H}, \mathrm{C} \beta-H^{\text {Phe(4-I) }}\right), 1.83\left(\mathrm{~s}, 3 \mathrm{H}, \mathrm{CH}_{3}\right), 1.10\left(\mathrm{~d},{ }^{3} \mathrm{~J}=\right.$ $\left.7.2 \mathrm{~Hz}, 3 \mathrm{H}, \mathrm{C} \beta-\mathrm{H}^{\mathrm{Ala}}\right)$.

${ }^{13} \mathrm{C}$ NMR $\left(121 \mathrm{MHz}\right.$, DMSO- $\left.d_{6}\right): \delta=172.1(\mathrm{COOH}), 171.0\left(\mathrm{C}=\mathrm{O}^{\text {Phe }(4-\mathrm{I})}\right)$, $170.9\left(\mathrm{C}=\mathrm{O}^{\mathrm{Ala}}\right), 169.1\left(\mathrm{C}=\mathrm{O}^{\mathrm{Ac}}\right), 137.5(\mathrm{C} 1), 136.7(\mathrm{C} 2), 131.8(\mathrm{C} 3), 92.2$ (C4), $53.2\left(\mathrm{C}^{\text {Phe }(4-\mathrm{I})}\right), 48.1\left(\mathrm{C} \alpha^{\text {Ala }}\right), 40.6\left(\mathrm{C} \alpha^{\mathrm{Gly}}\right), 37.0\left(\mathrm{C} \beta^{\text {Phe }(4-\mathrm{I})}\right), 22.5$ $\left(\mathrm{CH}_{3}\right), 17.8\left(\mathrm{C} \beta^{\mathrm{Ala}}\right)$.

LC-MS (ESI): $m / z$ [M + H] $]^{+}$calcd: 461.04 ; found: 461.05 .

\section{Ac-Ser-Phe(4-I)-Gly-OH (7)}

Synthesized by solid-phase peptide synthesis (SPPS) on a 2-chlorotrityl resin on a $0.1 \mathrm{mmol}$ scale. The product 7 was isolated after reverse-phase HPLC purification.

Yield: $24.6 \mathrm{mg}$ ( $51 \mu \mathrm{mol}, 51 \%)$; colorless solid.

${ }^{1} \mathrm{H}$ NMR (600 MHz, DMSO- $\left.d_{6}\right): \delta=12.46$ (br s, $\left.1 \mathrm{H}, \mathrm{COOH}\right), 8.34\left(\mathrm{t},{ }^{3} \mathrm{~J}=\right.$ $\left.5.9 \mathrm{~Hz}, 1 \mathrm{H}, \mathrm{CON} H^{\mathrm{Gly}}\right), 7.99\left(\mathrm{~d},{ }^{3} \mathrm{~J}=8.4 \mathrm{~Hz}, 1 \mathrm{H}, \mathrm{CONH}^{\text {Phe(4-I) }}\right), 7.88\left(\mathrm{~d},{ }^{3} \mathrm{~J}=\right.$ $\left.7.8 \mathrm{~Hz}, 1 \mathrm{H}, \mathrm{CONH}{ }^{\mathrm{Ser}}\right), 7.57\left(\mathrm{~d},{ }^{3} \mathrm{~J}=8.3 \mathrm{~Hz}, 2 \mathrm{H}, \mathrm{C} 3-H\right), 7.05\left(\mathrm{~d},{ }^{3} \mathrm{~J}=8.2\right.$ $\mathrm{Hz}, 2 \mathrm{H}, \mathrm{C} 2-\mathrm{H}$ ), 4.96 (br s, $1 \mathrm{H}, \mathrm{OH}$ ), 4.50 (ddd, ${ }^{3} \mathrm{~J}=9.2 \mathrm{~Hz},{ }^{3} \mathrm{~J}=8.1 \mathrm{~Hz}$, $\left.{ }^{3} J=4.3 \mathrm{~Hz}, 1 \mathrm{H}, \mathrm{C} \alpha-H^{\text {Phe(}(4-\mathrm{I})}\right), 4.25\left(\mathrm{ddd},{ }^{3} J=7.8 \mathrm{~Hz},{ }^{3} \mathrm{~J}=6.2 \mathrm{~Hz},{ }^{3} \mathrm{~J}=6.2\right.$ $\left.\mathrm{Hz}, 1 \mathrm{H}, \mathrm{C} \alpha-H^{\mathrm{Ser}}\right), 3.76\left(\mathrm{~d},{ }^{3} \mathrm{~J}=6.0 \mathrm{~Hz}, 2 \mathrm{H}, \mathrm{C} \alpha-H^{\mathrm{Gly}}\right), 3.47\left(\mathrm{~d},{ }^{3} \mathrm{~J}=6.4 \mathrm{~Hz}\right.$, $\left.2 \mathrm{H}, \mathrm{C} \beta-H^{\mathrm{Ser}}\right), 3.02\left(\mathrm{dd},{ }^{2} \mathrm{~J}=13.9 \mathrm{~Hz},{ }^{3} \mathrm{~J}=4.4 \mathrm{~Hz}, 1 \mathrm{H}, \mathrm{C} \beta-H^{\text {Phe }(4-\mathrm{I})}\right), 2.75$ $\left(\mathrm{dd},{ }^{2} \mathrm{~J}=14.1 \mathrm{~Hz},{ }^{3} \mathrm{~J}=9.4 \mathrm{~Hz}, 1 \mathrm{H}, \mathrm{C} \beta-H^{\text {Phe(4-I) }}\right), 1.83\left(\mathrm{~s}, 3 \mathrm{H}, \mathrm{CH}_{3}\right)$. 
${ }^{13} \mathrm{C}$ NMR (151 MHz, DMSO- $\left.d_{6}\right): \delta=171.0(\mathrm{COOH}), 170.9\left(\mathrm{C}=\mathrm{O}^{\text {Phe }(4-\mathrm{I})}\right)$, $170.1\left(\mathrm{C}=\mathrm{O}^{\mathrm{Ser}}\right), 169.4\left(\mathrm{C}=\mathrm{O}^{\mathrm{AC}}\right), 137.5(\mathrm{C} 1), 136.7(\mathrm{C} 2), 131.7(\mathrm{C} 3), 92.2$ (C4), $61.7\left(\mathrm{C} \beta^{\text {Ser }}\right), 54.9\left(\mathrm{C} \alpha^{\text {Ser }}\right), 53.5\left(\mathrm{C} \alpha^{\text {Phe }(4-\mathrm{I})}\right), 40.7\left(\mathrm{C} \alpha^{\mathrm{Gly}}\right), 36.8$ $\left(\mathrm{C} \beta^{\text {Phe(4-I) }}\right), 22.6\left(\mathrm{CH}_{3}\right)$.

LC-MS (ESI): $m / z$ [M + H] $]^{+}$calcd: 477.04; found: 477.04 .

\section{Ac-Phe-Phe(4-I)-Gly-OH (8)}

Synthesized by solid-phase peptide synthesis (SPPS) on a 2-chlorotrityl resin according on a $0.1 \mathrm{mmol}$ scale. The product 8 was isolated after reverse-phase HPLC purification.

Yield: $14.4 \mathrm{mg}$ ( $27 \mu \mathrm{mol}, 27 \%)$; colorless solid.

${ }^{1} \mathrm{H}$ NMR $\left(600 \mathrm{MHz}\right.$, DMSO- $\left.d_{6}\right): \delta=12.63$ (br s, $\left.1 \mathrm{H}, \mathrm{COOH}\right), 8.25\left(\mathrm{t},{ }^{3} \mathrm{~J}=\right.$ $\left.5.9 \mathrm{~Hz}, 1 \mathrm{H}, \mathrm{CONH} H^{\mathrm{Gly}}\right), 8.08\left(\mathrm{~d},{ }^{3} \mathrm{~J}=8.5 \mathrm{~Hz}, 2 \mathrm{H}, \mathrm{CONH} H^{\mathrm{Phe}}\right), 8.00\left(\mathrm{~d},{ }^{3} \mathrm{~J}=\right.$ $\left.8.4 \mathrm{~Hz}, 1 \mathrm{H}, \mathrm{CONH}^{\mathrm{Phe}(4-\mathrm{I})}\right), 7.59\left(\mathrm{~d},{ }^{3} \mathrm{~J}=8.0 \mathrm{~Hz}, 2 \mathrm{H}, \mathrm{C} 3-H\right), 7.23\left(\mathrm{t},{ }^{3} \mathrm{~J}=7.5\right.$ $\left.\mathrm{Hz}, 2 \mathrm{H}, \mathrm{C} 2^{\prime}-H\right), 7.20-7.14$ (m, 3 H, C3'-H/C4'-H), 7.06 (d, ${ }^{3} \mathrm{~J}=7.8 \mathrm{~Hz}, 2$ $\mathrm{H}, \mathrm{C} 2-H), 4.53\left(\mathrm{ddd},{ }^{3} \mathrm{~J}=9.2 \mathrm{~Hz},{ }^{3} \mathrm{~J}=8.1 \mathrm{~Hz},{ }^{3} \mathrm{~J}=4.3 \mathrm{~Hz}, 1 \mathrm{H}, \mathrm{C} \alpha-H^{\text {Phe }(4-\mathrm{I})}\right.$ ), $4.47\left(\mathrm{ddd},{ }^{3} \mathrm{~J}=10.1 \mathrm{~Hz},{ }^{3} \mathrm{~J}=8.4 \mathrm{~Hz},{ }^{3} \mathrm{~J}=4.5 \mathrm{~Hz}, 1 \mathrm{H}, \mathrm{C} \alpha-H^{\text {Phe }}\right), 3.82-3.71$ $\left(\mathrm{m}, 2 \mathrm{H}, \mathrm{C} \alpha-H^{\mathrm{Gly}}\right), 3.00\left(\mathrm{dd},{ }^{2} \mathrm{~J}=13.9 \mathrm{~Hz},{ }^{3} \mathrm{~J}=4.4 \mathrm{~Hz}, 2 \mathrm{H}, \mathrm{C} \beta-H^{\mathrm{Ph}(4-\mathrm{I})}\right)$, $2.93\left(\mathrm{dd},{ }^{2} \mathrm{~J}=13.9 \mathrm{~Hz},{ }^{3} \mathrm{~J}=4.6 \mathrm{~Hz}, 2 \mathrm{H}, \mathrm{C} \beta-H^{\text {phe }}\right), 2.75\left(\mathrm{dd},{ }^{2} J=13.9 \mathrm{~Hz}\right.$, $\left.{ }^{3} J=9.3 \mathrm{~Hz}, 1 \mathrm{H}, \mathrm{C} \beta-H^{\text {Phe }(4-\mathrm{I})}\right), 2.65\left(\mathrm{dd},{ }^{2} J=14.0 \mathrm{~Hz},{ }^{3} J=10.0 \mathrm{~Hz}, 1 \mathrm{H}, \mathrm{C} \beta-\right.$ $\left.H^{\text {Phe }}\right), 1.72(\mathrm{~s}, 5 \mathrm{H})$.

${ }^{13} \mathrm{C}$ NMR $\left(151 \mathrm{MHz}\right.$, DMSO- $\left.d_{6}\right): \delta=171.2(\mathrm{COOH}), 171.0\left(\mathrm{C}=\mathrm{O}^{\text {Phe }(4-\mathrm{I})}\right)$, $170.9\left(\mathrm{C}=\mathrm{O}^{\mathrm{Ac}}\right), 169.0\left(\mathrm{C}=\mathrm{O}^{\text {Phe }}\right), 138.0\left(\mathrm{C} 1^{\prime}\right), 137.4(\mathrm{C} 1), 136.7(\mathrm{C} 2), 131.8$ (C3), 129.1 (C3'), 128.0 (C2'), 126.1 (C4'), 92.2 (C4), 53.7 (Ca $\left.{ }^{\text {Phe }}\right), 53.3$

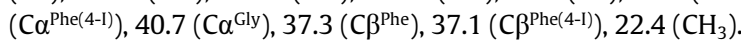

LC-MS (ESI): $m / z$ [M + H] $]^{+}$calcd: 537.08; found: 537.07 .

\section{Ac-Ala-Phe(4-Ph)-Gly-OH (9)}

Ac-Ala-Phe(4-I)-Gly-OH (7) (4.6 mg, $10 \mu \mathrm{mol}$ ), phenylboronic acid ( $2.4 \mathrm{mg}, 20 \mu \mathrm{mol}, 2$ equiv) and $\mathrm{K}_{3} \mathrm{PO}_{4}$ aq. ( $500 \mathrm{~mm}, 100 \mu \mathrm{L}, 5$ equiv) were mixed and heated to $37^{\circ} \mathrm{C}$ followed by addition of PNIPAM-DAPMA-functionalized microgel carried Pd-nanoparticles $(0.78 \mathrm{mM}, 624$ $\mu \mathrm{L}, 5.0 \mathrm{~mol} \%)$ and water $(276 \mu \mathrm{L})$. After 48 hours and $41 \%$ conversion, the Pd-nanoparticles were removed by centrifugation ( $10000 \mathrm{rpm}, 10$ $\mathrm{min}$ ) and the reaction mixture was purified by RP-HPLC, giving AcAla-Phe(4-Ph)-Gly-OH (9).

Yield: $1.6 \mathrm{mg}$ (3.8 $\mu \mathrm{mol}, 38 \%)$; colorless solid.

${ }^{1} \mathrm{H}$ NMR $\left(600 \mathrm{MHz}\right.$, DMSO- $\left.d_{6}\right): \delta=12.60$ (br s, $\left.1 \mathrm{H}, \mathrm{COOH}\right), 8.32\left(\mathrm{t},{ }^{3} \mathrm{~J}=\right.$ $\left.5.9 \mathrm{~Hz}, 1 \mathrm{H}, \mathrm{CON} H^{\mathrm{Gly}}\right), 7.98\left(\mathrm{~d},{ }^{3} \mathrm{~J}=7.4 \mathrm{~Hz}, 1 \mathrm{H}, \mathrm{CON} H^{\mathrm{Ala}}\right), 7.93\left(\mathrm{~d},{ }^{3} \mathrm{~J}=8.4\right.$ $\left.\mathrm{Hz}, 1 \mathrm{H}, \mathrm{CONH}^{\mathrm{Phe}}\right), 7.63$ (dd, ${ }^{3} \mathrm{~J}=8.4 \mathrm{~Hz},{ }^{4} \mathrm{~J}=1.4 \mathrm{~Hz}, 2 \mathrm{H}, \mathrm{C2}$ '- $H$ ), 7.54 (d, $\left.{ }^{3} J=8.3 \mathrm{~Hz}, 2 \mathrm{H}, \mathrm{C} 3-\mathrm{H}\right), 7.45\left(\mathrm{dd},{ }^{3} J=7.8 \mathrm{~Hz},{ }^{3} \mathrm{~J}=7.8 \mathrm{~Hz}, 2 \mathrm{H}, \mathrm{C}^{\prime}-\mathrm{H}\right)$, 7.36-7.30 (m, $\left.3 \mathrm{H}, \mathrm{C} 2-H / \mathrm{C}^{\prime}-H\right), 4.55\left(\mathrm{ddd},{ }^{3} \mathrm{~J}=9.1 \mathrm{~Hz},{ }^{3} \mathrm{~J}=8.2 \mathrm{~Hz},{ }^{3} \mathrm{~J}=\right.$ $\left.4.5 \mathrm{~Hz}, 1 \mathrm{H}, \mathrm{C} \alpha-H^{\text {Phe }}\right), 4.23\left(\mathrm{dq},{ }^{3} J=7.1 \mathrm{~Hz},{ }^{3} J=7.1 \mathrm{~Hz}, 1 \mathrm{H}, \mathrm{C} \alpha-H^{\text {Ala }}\right)$, $3.81\left(\mathrm{dd},{ }^{2} \mathrm{~J}=17.6 \mathrm{~Hz},{ }^{3} J=5.9 \mathrm{~Hz}, 1 \mathrm{H}, \mathrm{C} \alpha-H^{\mathrm{Gly}}\right), 3.77\left(\mathrm{dd},{ }^{2} J=17.5 \mathrm{~Hz}\right.$, $\left.{ }^{3} J=5.8 \mathrm{~Hz}, 1 \mathrm{H}, \mathrm{C} \alpha-H^{\mathrm{Gly}}\right), 3.09\left(\mathrm{dd},{ }^{2} \mathrm{~J}=13.9 \mathrm{~Hz},{ }^{3} \mathrm{~J}=4.5 \mathrm{~Hz}, 1 \mathrm{H}, \mathrm{C} \beta-\right.$ $\left.H^{\text {Phe }}\right), 2.85\left(\mathrm{dd},{ }^{2} \mathrm{~J}=13.9 \mathrm{~Hz},{ }^{3} \mathrm{~J}=9.4 \mathrm{~Hz}, 1 \mathrm{H}, \mathrm{C} \beta-H^{\text {Phe }}\right), 1.79\left(\mathrm{~s}, 3 \mathrm{H}, \mathrm{CH}_{3}\right)$, $1.11\left(\mathrm{~d},{ }^{3} \mathrm{~J}=7.1 \mathrm{~Hz}, 3 \mathrm{H}, \mathrm{CH}_{3}{ }^{\mathrm{Ala}}\right)$.

${ }^{13} \mathrm{C}$ NMR (151 MHz, DMSO- $\left.d_{6}\right): \delta=172.2\left(\mathrm{C}=\mathrm{O}^{\mathrm{Ala}}\right), 171.2\left(\mathrm{C}=\mathrm{O}^{\mathrm{Phe}}\right)$, $171.1(\mathrm{COOH}), 169.1\left(\mathrm{C}=\mathrm{O}^{\mathrm{Ac}}\right), 140.0\left(\mathrm{C1}^{\prime}\right), 138.1(\mathrm{C} 4), 137.0(\mathrm{C} 1), 129.9$ (C2), 128.9 (C3'), 127.2 (C4'), 126.5 (C2'), 126.3 (C3), 53.5 (Ca $\left.{ }^{\text {Phe }}\right), 48.2$ ( $\left.\mathrm{C} \alpha^{\text {Ala }}\right), 40.7$ ( $\left.\mathrm{C} \alpha^{\text {Gly }}\right), 37.1$ (C $\left.\beta^{\text {Phe }}\right), 22.5\left(\mathrm{CH}_{3}\right), 17.9\left(\mathrm{CH}_{3}{ }^{\mathrm{Ala}}\right)$.

LC-MS (ESI): $m / z$ [M + H] $]^{+}$calcd: 411.18 ; found: 411.18.

\section{Ac-Ser-Phe(4-Ph)-Gly-OH (10)}

Ac-Ala-Phe(4-I)-Gly-OH (8) (4.9 mg, $10 \mu \mathrm{mol})$, phenylboronic acid ( $2.4 \mathrm{mg}, 20 \mu \mathrm{mol}, 2$ equiv) and $\mathrm{K}_{3} \mathrm{PO}_{4}$ aq. ( $500 \mathrm{~mm}, 100 \mu \mathrm{L}, 5$ equiv) were mixed and heated to $37{ }^{\circ} \mathrm{C}$ followed by addition of PNNPAMDAPMA-functionalized microgel carried Pd-nanoparticles $(0.57 \mathrm{mM}$,
$926 \mu \mathrm{L}, 5.0 \mathrm{~mol} \%$ ). After full conversion, the Pd-nanoparticles were removed by centrifugation ( $10000 \mathrm{rpm}, 10 \mathrm{~min}$ ) and the reaction mixture was purified by RP-HPLC, giving Ac-Ser-Phe(4-Ph)-Gly-OH (10). Yield: $3.4 \mathrm{mg}$ ( $7.9 \mu \mathrm{mol}, 79 \%)$; colorless solid.

${ }^{1} \mathrm{H}$ NMR (600 MHz, DMSO- $d_{6}$ ): $\delta=12.60$ (br s, $\left.1 \mathrm{H}, \mathrm{COOH}\right), 8.36\left(\mathrm{t},{ }^{3} \mathrm{~J}=\right.$ $\left.5.9 \mathrm{~Hz}, 1 \mathrm{H}, \mathrm{CONH} H^{\mathrm{Gly}}\right), 8.05\left(\mathrm{~d},{ }^{3} \mathrm{~J}=7.9 \mathrm{~Hz}, 1 \mathrm{H}, \mathrm{CONH}{ }^{\mathrm{Ser}}\right), 7.89\left(\mathrm{~d},{ }^{3} \mathrm{~J}=7.8\right.$ $\left.\mathrm{Hz}, 1 \mathrm{H}, \mathrm{CON} H^{\text {Phe }}\right), 7.64\left(\mathrm{~d},{ }^{3} \mathrm{~J}=7.8,2 \mathrm{H}, \mathrm{C} 2^{\prime}-H\right), 7.54\left(\mathrm{~d},{ }^{3} \mathrm{~J}=8.3 \mathrm{~Hz}, 2 \mathrm{H}\right.$, C3-H), $7.45\left(\mathrm{dd},{ }^{3} \mathrm{~J}=7.7 \mathrm{~Hz},{ }^{3} \mathrm{~J}=7.7 \mathrm{~Hz}, 2 \mathrm{H}, \mathrm{C} 3^{\prime}-H\right), 7.38-7.25(\mathrm{~m}, 3 \mathrm{H}$, C2- $\mathrm{H} / \mathrm{CC}^{\prime}-\mathrm{H}$ ), 4.97 (br s, $1 \mathrm{H}, \mathrm{OH}$ ), 4.56 (ddd, ${ }^{3} \mathrm{~J}=8.9 \mathrm{~Hz},{ }^{3} \mathrm{~J}=7.8 \mathrm{~Hz},{ }^{3} \mathrm{~J}=$ $4.3 \mathrm{~Hz}, 1 \mathrm{H}, \mathrm{C \alpha}-\mathrm{H}^{\text {Phe }}$ ), 4.29 (ddd, ${ }^{3} \mathrm{~J}=10.4 \mathrm{~Hz},{ }^{3} \mathrm{~J}=8.7 \mathrm{~Hz},{ }^{3} \mathrm{~J}=7.2 \mathrm{~Hz}, 1$ $\left.\mathrm{H}, \mathrm{C} \alpha-H^{\text {Ser }}\right), 3.79\left(\mathrm{~d},{ }^{3} J=5.9 \mathrm{~Hz}, 2 \mathrm{H}, \mathrm{C} \alpha-H^{\mathrm{Gly}}\right), 3.49\left(\mathrm{~m}, 2 \mathrm{H}, \mathrm{C} \beta-H^{\text {Ser }}\right)$, $3.12\left(\mathrm{dd},{ }^{2} \mathrm{~J}=13.9 \mathrm{~Hz},{ }^{3} \mathrm{~J}=4.4 \mathrm{~Hz}, 1 \mathrm{H}, \mathrm{C} \beta-H^{\mathrm{Phe}}\right), 2.86\left(\mathrm{dd},{ }^{2} J=13.9 \mathrm{~Hz}\right.$, $\left.{ }^{3} \mathrm{~J}=9.4 \mathrm{~Hz}, 1 \mathrm{H}, \mathrm{C} \beta-H^{\text {Phe }}\right), 1.82\left(\mathrm{~s}, 3 \mathrm{H}, \mathrm{CH}_{3}\right)$.

${ }^{13} \mathrm{C}$ NMR (151 MHz, DMSO- $\left.d_{6}\right): \delta=171.2\left(\mathrm{C}=\mathrm{O}^{\mathrm{Ser}}\right), 171.0\left(\mathrm{C}=\mathrm{O}^{\mathrm{Phe}}\right)$, $170.1(\mathrm{COOH}), 169.4\left(\mathrm{C}=\mathrm{O}^{\mathrm{Ac}}\right), 140.0\left(\mathrm{C}^{\prime}\right), 138.1(\mathrm{C} 4), 137.1(\mathrm{C} 1), 129.9$ (C2), 128.9 (C3'), 127.2 (C4'), 126.5 (C2'), 126.3 (C3), $61.71\left(\mathrm{C} \beta^{\text {Ser }}\right), 54.9$ $\left(\mathrm{C} \alpha^{\text {Ser }}\right), 53.8\left(\mathrm{C} \alpha^{\text {Phe }}\right), 40.7$ ( $\left.\mathrm{C}^{\text {Gly }}\right), 36.9\left(\mathrm{C}^{\text {Phe }}\right), 22.5\left(\mathrm{CH}_{3}\right)$.

LC-MS (ESI): $m / z$ [M + H] $]^{+}$calcd: 427.17 ; found: 427.17 .

\section{Ac-Met-Val-Trp(7-Br)-OH (12)}

Synthesized by solid-phase peptide synthesis (SPPS) on a 2-chlorotrityl resin on a $0.118 \mathrm{mmol}$ scale. The product 12 was isolated after reversed-phase HPLC purification.

Yield: $63.4 \mathrm{mg}$ (114 $\mu \mathrm{mol}, 97 \%)$; colorless solid.

${ }^{1} \mathrm{H}$ NMR (600 MHz, DMSO- $d_{6}$ ): $\delta=12.61$ (br s, $\left.1 \mathrm{H}, \mathrm{COOH}\right), 11.06$ (d, ${ }^{3} \mathrm{~J}=2.6 \mathrm{~Hz}, 1 \mathrm{H}$, indole-NH), $8.21\left(\mathrm{~d},{ }^{3} \mathrm{~J}=8.4 \mathrm{~Hz}, 1 \mathrm{H}, \mathrm{CONH} H^{\mathrm{Trp}}\right), 8.07$ (d, $\left.{ }^{3} \mathrm{~J}=8.1 \mathrm{~Hz}, 1 \mathrm{H}, \mathrm{CONH} H^{\mathrm{Met}}\right), 7.66\left(\mathrm{~d},{ }^{3} \mathrm{~J}=8.9 \mathrm{~Hz}, 1 \mathrm{H}, \mathrm{CONH}{ }^{\mathrm{Val}}\right), 7.54(\mathrm{~d}$, $\left.{ }^{3} \mathrm{~J}=7.8 \mathrm{~Hz}, 1 \mathrm{H}, \mathrm{C} 4-\mathrm{H}\right), 7.28\left(\mathrm{dd},{ }^{3} \mathrm{~J}=7.5 \mathrm{~Hz},{ }^{4} \mathrm{~J}=1.7 \mathrm{~Hz}, 1 \mathrm{H}, \mathrm{C} 6-H\right), 7.23$ $\left(\mathrm{d},{ }^{3} \mathrm{~J}=2.6 \mathrm{~Hz}, 1 \mathrm{H}, \mathrm{C} 2-\mathrm{H}\right), 6.94\left(\mathrm{dd},{ }^{3} \mathrm{~J}=7.7 \mathrm{~Hz}, 1 \mathrm{H}, \mathrm{C} 4-\mathrm{H}\right), 4.47$ (ddd, $\left.{ }^{3} \mathrm{~J}=9.3 \mathrm{~Hz},{ }^{3} \mathrm{~J}=7.4 \mathrm{~Hz},{ }^{3} \mathrm{~J}=5.4 \mathrm{~Hz}, 1 \mathrm{H}, \mathrm{C} \alpha-H^{\mathrm{Trp}}\right), 4.36\left(\mathrm{ddd},{ }^{3} \mathrm{~J}=10.3 \mathrm{~Hz}\right.$, $\left.{ }^{3} \mathrm{~J}=8.6 \mathrm{~Hz},{ }^{3} \mathrm{~J}=4.9 \mathrm{~Hz}, 1 \mathrm{H}, \mathrm{C \alpha}-H^{\mathrm{Met}}\right), 4.20\left(\mathrm{dd},{ }^{3} \mathrm{~J}=8.9,{ }^{3} \mathrm{~J}=6.5 \mathrm{~Hz}, 1 \mathrm{H}\right.$, $\left.\mathrm{C} \alpha-H^{\mathrm{Val}}\right), 3.13\left(\mathrm{dd},{ }^{3} \mathrm{~J}=14.9 \mathrm{~Hz},{ }^{3} \mathrm{~J}=5.6 \mathrm{~Hz}, 1 \mathrm{H}, \mathrm{C} \beta-H^{\mathrm{Trp}}\right), 3.04\left(\mathrm{dd},{ }^{3} J=\right.$ $\left.14.9 \mathrm{~Hz},{ }^{3} \mathrm{~J}=7.6 \mathrm{~Hz}, 1 \mathrm{H}, \mathrm{C} \beta-H^{\mathrm{Trp}}\right), 2.46-2.35$ (m, $\left.2 \mathrm{H}, \mathrm{C} \gamma-H^{\mathrm{Met}}\right), 1.98$ (s, $\left.3 \mathrm{H}, \mathrm{SCH}_{3}\right), 1.95\left(\mathrm{dq},{ }^{3} \mathrm{~J}=8.6 \mathrm{~Hz},{ }^{3} \mathrm{~J}=6.8 \mathrm{~Hz},{ }^{3} \mathrm{~J}=6.8 \mathrm{~Hz}, 1 \mathrm{H}\right), 1.89-1.81$ $\left(\mathrm{m}, 4 \mathrm{H}, \mathrm{CH}_{3} / \mathrm{C} \beta-H^{\mathrm{Met}}\right), 1.73\left(\mathrm{ddt},{ }^{3} \mathrm{~J}=13.5 \mathrm{~Hz},{ }^{3} \mathrm{~J}=9.1 \mathrm{~Hz},{ }^{3} \mathrm{~J}=6.0 \mathrm{~Hz}, 1\right.$ $\left.\mathrm{H}, \mathrm{C} \beta-H^{\mathrm{Met}}\right), 0.82\left(\mathrm{~d},{ }^{3} \mathrm{~J}=6.8 \mathrm{~Hz}, 3 \mathrm{H}, \mathrm{C} \gamma-H^{\mathrm{Val}}\right), 0.79\left(\mathrm{~d},{ }^{3} \mathrm{~J}=6.8 \mathrm{~Hz}, 3 \mathrm{H}\right.$, $\left.\mathrm{C} \gamma-H^{\mathrm{Val}}\right)$.

${ }^{13} \mathrm{C}$ NMR (151 MHz, DMSO-d $\left.\mathrm{d}_{6}\right): \delta=172.9(\mathrm{COOH}), 171.1\left(\mathrm{C}=\mathrm{O}^{\mathrm{Met}}\right)$, $170.8\left(C=\mathrm{O}^{\text {Trp }}\right), 169.3\left(\mathrm{C}=\mathrm{O}^{\mathrm{Ac}}\right), 134.3(\mathrm{C} 7 \mathrm{a}), 129.0(\mathrm{C} 3 \mathrm{a}), 125.0(\mathrm{C} 2)$, 123.5 (C6), 119.9 (C5), 117.8 (C4), 111.2 (C3), 104.2 (C7), $57.2\left(\mathrm{Ca}^{\mathrm{Val}}\right)$, $52.8\left(\mathrm{C} \alpha^{\mathrm{Tr} p}\right), 51.8\left(\mathrm{C} \alpha^{\mathrm{Met}}\right), 31.7\left(\mathrm{C} \beta^{\mathrm{Met}}\right), 30.8\left(\mathrm{C} \beta^{\mathrm{Val}}\right), 29.6\left(\mathrm{C} \gamma^{\mathrm{Met}}\right), 27.0$ $\left(\mathrm{C} \beta^{\mathrm{Trp}}\right), 22.5\left(\mathrm{CH}_{3}\right), 19.1\left(\mathrm{C} \gamma^{\mathrm{Val}}\right), 17.8\left(\mathrm{C}^{\mathrm{Val}}\right), 14.6\left(\mathrm{SCH}_{3}\right)$.

LC-MS (ESI): $m / z$ calcd: $554.12\left[\mathrm{M}\left({ }^{79} \mathrm{Br}\right)+\mathrm{H}\right]^{+}, 556.12\left[\mathrm{M}\left({ }^{81} \mathrm{Br}\right)+\mathrm{H}\right]^{+}$; found: $554.12\left[\mathrm{M}\left({ }^{79} \mathrm{Br}\right)+\mathrm{H}\right]^{+}, 556.12\left[\mathrm{M}\left({ }^{81} \mathrm{Br}\right)+\mathrm{H}\right]^{+}$.

\section{Ac-Met-Asp-Gly-Trp(7-Br)-OH (13)}

Synthesized by solid-phase peptide synthesis (SPPS) on a 2-chlorotrityl resin on a $0.118 \mathrm{mmol}$ scale. The product 13 was isolated after reversed-phase HPLC purification.

Yield: $56.0 \mathrm{mg}$ ( $89 \mu \mathrm{mol}, 76 \%)$; colorless solid.

${ }^{1} \mathrm{H}$ NMR $\left(600 \mathrm{MHz}\right.$, DMSO- $d_{6}$ ): $\delta=12.66$ (br s, $1 \mathrm{H}, \mathrm{COOH}$ ), 12.36 (br s, $\left.1 \mathrm{H}, \mathrm{COOH}^{\mathrm{Asp}}\right), 11.10\left(\mathrm{~d},{ }^{3} \mathrm{~J}=2.6 \mathrm{~Hz}, 1 \mathrm{H}\right.$, indole- $\left.\mathrm{NH}\right), 8.27\left(\mathrm{~d},{ }^{3} \mathrm{~J}=7.6\right.$ $\left.\mathrm{Hz}, 1 \mathrm{H}, \mathrm{CONH}{ }^{\mathrm{Asp}}\right), 8.09\left(\mathrm{~d},{ }^{3} \mathrm{~J}=7.5 \mathrm{~Hz}, 1 \mathrm{H}, \mathrm{CONH} \mathrm{Het}^{\mathrm{Met}}\right), 8.05\left(\mathrm{~d},{ }^{3} \mathrm{~J}=7.8\right.$ $\left.\mathrm{Hz}, 1 \mathrm{H}, \mathrm{CONH}^{\mathrm{Tr} \mathrm{p}}\right), 7.94\left(\mathrm{t},{ }^{3} \mathrm{~J}=5.8 \mathrm{~Hz}, 1 \mathrm{H}, \mathrm{CON} H^{\mathrm{Gly}}\right), 7.55\left(\mathrm{~d},{ }^{3} \mathrm{~J}=7.9 \mathrm{~Hz}\right.$, $1 \mathrm{H}, \mathrm{C} 4-\mathrm{H}), 7.29\left(\mathrm{~d},{ }^{3} \mathrm{~J}=7.4 \mathrm{~Hz}, 1 \mathrm{H}, \mathrm{C} 6-\mathrm{H}\right), 7.22\left(\mathrm{~d},{ }^{3} \mathrm{~J}=2.7 \mathrm{~Hz}, 1 \mathrm{H}, \mathrm{C} 2-\right.$ $H$ ), $6.95\left(\mathrm{dd},{ }^{3} \mathrm{~J}=7.7 \mathrm{~Hz},{ }^{3} \mathrm{~J}=7.7 \mathrm{~Hz}, 1 \mathrm{H}, \mathrm{C} 5-H\right), 4.52\left(\mathrm{ddd},{ }^{3} \mathrm{~J}=8.2 \mathrm{~Hz}\right.$, $\left.{ }^{3} J=7.7 \mathrm{~Hz},{ }^{3} \mathrm{~J}=5.1 \mathrm{~Hz}, 1 \mathrm{H}, \mathrm{C} \alpha-H^{\text {Asp }}\right), 4.47$ (ddd, ${ }^{3} \mathrm{~J}=8.0 \mathrm{~Hz},{ }^{3} \mathrm{~J}=7.9 \mathrm{~Hz}$, $\left.{ }^{3} J=5.3 \mathrm{~Hz}, 1 \mathrm{H}, \mathrm{C} \alpha-H^{\mathrm{Trp}}\right), 4.29\left(\mathrm{ddd},{ }^{3} J=8.2 \mathrm{~Hz},{ }^{3} J=7.5 \mathrm{~Hz},{ }^{3} J=5.0 \mathrm{~Hz}, 1\right.$ $\left.\mathrm{H}, \mathrm{C} \alpha-H^{\mathrm{Met}}\right), 3.70\left(\mathrm{dd},{ }^{3} \mathrm{~J}=16.8 \mathrm{~Hz},{ }^{3} \mathrm{~J}=5.8 \mathrm{~Hz}, 1 \mathrm{H}, \mathrm{C} \alpha-H^{\mathrm{Gly}}\right), 3.66(\mathrm{dd}$, 
$\left.{ }^{3} J=16.8 \mathrm{~Hz},{ }^{3} J=5.8 \mathrm{~Hz}, 1 \mathrm{H}, \mathrm{C} \alpha-H^{\mathrm{Gly}}\right), 3.17\left(\mathrm{dd},{ }^{3} J=14.7 \mathrm{~Hz},{ }^{3} J=5.4 \mathrm{~Hz}\right.$, $1 \mathrm{H}, \mathrm{C} \beta-H^{\mathrm{Tr}}$ ), $3.04\left(\mathrm{dd},{ }^{3} \mathrm{~J}=14.7 \mathrm{~Hz},{ }^{3} \mathrm{~J}=8.0 \mathrm{~Hz}, 1 \mathrm{H}, \mathrm{C} \beta-H^{\mathrm{Tr}}\right), 2.74(\mathrm{dd}$, $\left.{ }^{3} J=16.6 \mathrm{~Hz},{ }^{3} \mathrm{~J}=5.2 \mathrm{~Hz}, 1 \mathrm{H}, \mathrm{C} \beta-H^{\text {Asp }}\right), 2.56\left(\mathrm{dd},{ }^{3} \mathrm{~J}=16.6 \mathrm{~Hz},{ }^{3} \mathrm{~J}=8.2 \mathrm{~Hz}\right.$, $\left.1 \mathrm{H}, \mathrm{C} \beta-H^{\mathrm{Asp}}\right), 2.47-2.38\left(\mathrm{~m}, 2 \mathrm{H}, \mathrm{C} \gamma-H^{\mathrm{Met}}\right), 2.01$ (s, $\left.3 \mathrm{H}, \mathrm{SCH}_{3}\right), 1.90(\mathrm{~m}$, $\left.1 \mathrm{H}, \mathrm{C} \beta-H^{\mathrm{Met}}\right), 1.86\left(\mathrm{~s}, 3 \mathrm{H}, \mathrm{CH}_{3}\right), 1.76\left(\mathrm{ddt},{ }^{3} \mathrm{~J}=13.8 \mathrm{~Hz},{ }^{3} \mathrm{~J}=9.1 \mathrm{~Hz},{ }^{3} \mathrm{~J}=\right.$ $\left.5.6 \mathrm{~Hz}, 1 \mathrm{H}, \mathrm{C} \beta-\mathrm{H}^{\mathrm{Met}}\right)$.

${ }^{13} \mathrm{C}$ NMR (151 MHz, DMSO- $\left.d_{6}\right): \delta=172.9(\mathrm{COOH}), 171.9\left(\mathrm{COOH}^{\mathrm{Asp}}\right)$, $171.5\left(\mathrm{C}=\mathrm{O}^{\mathrm{Met}}\right), 170.6\left(\mathrm{C}=\mathrm{O}^{\mathrm{Asp}}\right), 169.8\left(\mathrm{C}=\mathrm{O}^{\mathrm{Ac}}\right), 168.4\left(\mathrm{C}=\mathrm{O}^{\mathrm{Gly}}\right), 134.3$ (C7a), 129.0 (C3a), 125.1 (C2), 123.5 (C6), 119.9 (C5), 117.8 (C4), 111.2 (C3), 104.2 (C7), 52.9 (C $\left.\alpha^{\text {Trp }}\right), 52.1\left(\mathrm{C}^{\text {Met }}\right), 49.6$ (C $\left.\alpha^{\text {Asp }}\right), 41.9$ (C $\left.\alpha^{\text {Gly }}\right)$, 35.9 (C $\left.\beta^{\text {Asp }}\right), 31.6$ (C $\left.\beta^{\text {Met }}\right), 29.5$ ( $\left.C \gamma^{\text {Val }}\right), 27.1\left(\mathrm{C} \beta^{\text {Trp }}\right), 22.5\left(\mathrm{CH}_{3}\right), 14.6$ $\left(\mathrm{SCH}_{3}\right)$.

LC-MS (ESI): $m / z$ calcd: $627.10\left[\mathrm{M}\left({ }^{79} \mathrm{Br}\right)+\mathrm{H}\right]^{+}, 629.10\left[\mathrm{M}\left({ }^{81} \mathrm{Br}\right)+\mathrm{H}\right]^{+}$; found: $627.10\left[\mathrm{M}\left({ }^{79} \mathrm{Br}\right)+\mathrm{H}\right]^{+}, 629.09\left[\mathrm{M}\left({ }^{81} \mathrm{Br}\right)+\mathrm{H}\right]^{+}$.

\section{Conflict of Interest}

The authors declare no conflict of interest.

\section{Funding Information}

We acknowledge financial support from Deutsche Forschungsgemeinschaft (SE 609/16-1).

\section{Acknowledgment}

The authors thank Bastian Altemeier and Jonas Runge for their assistance with microgel preparation. The OWL analytic center is thanked for measurement time on the TEM in Bielefeld.

\section{Supporting Information}

Supporting information for this article is available online at https://doi.org/10.1055/a-1782-4224.

\section{References}

(1) (a) Lennox, A. J. J.; Lloyd-Jones, G. C. Chem. Soc. Rev. 2014, 43, 412. (b) Suzuki, A. Angew. Chem. Int. Ed. 2011, 50, 6722. (c) Miyaura, N.; Suzuki, A. Chem. Rev. 1995, 95, 2457.

(2) (a) Willemse, T.; Schepens, W.; Vlijmen, H.; Maes, B.; Ballet, S. Catalysts 2017, 7, 74. (b) Gruß, H.; Sewald, N. Chem. Eur. J. 2020, 26, 5328.

(3) Dachwitz, S.; Duwe, D. H.; Wang, Y. H.; Gruß, H.; Hannappel, Y.; Hellweg, T.; Sewald, N. Chem. Eur. J. 2020, 26, 16357.

(4) Chalker, J. M.; Wood, C. S. C.; Davis, B. G. J. Am. Chem. Soc. 2009, $131,16346$.

(5) Roy, A. D.; Goss, R. J. M.; Wagner, G. K.; Winn, M. Chem. Commun. 2008, 4831.

(6) Willemse, T.; Van Imp, K.; Goss, R. J. M.; Van Vlijmen, H. W. T.; Schepens, W.; Maes, B. U. W.; Ballet, S. ChemCatChem 2015, 7, 2055.

(7) (a) Frese, M.; Schnepel, C.; Minges, H.; Voß, H.; Feiner, R.; Sewald, N. ChemCatChem 2016, 8, 1799. (b) Latham, J.; Henry, J.M.; Sharif, H. H.; Menon, B. R. K.; Shepherd, S. A.; Greaney, M. F.; Micklefield, J. Nat. Commun. 2016, 7, 11873.

(8) Schnepel, C.; Minges, H.; Frese, M.; Sewald, N. Angew. Chem. Int. Ed. 2016, 55, 14159.
(9) Sharma, S. V.; Tong, X.; Pubill-Ulldemolins, C.; Cartmell, C.; Bogosyan, E. J. A.; Rackham, E. J.; Marelli, E.; Hamed, R. B.; Goss, R. J. M. Nat. Commun. 2017, 8, 229.

(10) (a) Kemker, I.; Schnepel, C.; Schröder, D. C.; Marion, A.; Sewald, N. J. Med. Chem. 2019, 62, 7417. (b) Kemker, I.; Feiner, R. C.; Müller, K. M.; Sewald, N. ChemBioChem 2020, 21, 496.

(11) Liu, C.; Li, X. Chem. Rec. 2016, 16, 84.

(12) Dumas, A.; Peramo, A.; Desmaële, D.; Couvreur, P. Chimia 2016, 70, 252.

(13) Peramo, A.; Abdellah, I.; Pecnard, S.; Mougin, J.; Martini, C.; Couvreur, P.; Huc, V.; Desmaële, D. Molecules 2020, 25, 1459.

(14) Seto, H.; Morii, T.; Yoneda, T.; Murakami, T.; Hoshino, Y.; Miura, Y. Chem. Lett. 2013, 42, 301.

(15) Pelton, R. H.; Chibante, P. Colloids Surf. 1986, 20, 247.

(16) Saunders, B. R.; Vincent, B. Adv. Colloid Interface Sci. 1999, 80, 1.

(17) (a) Hoare, T.; Pelton, R. Langmuir 2008, 24, 1005. (b) Dirksen, M.; Kinder, T. A.; Brändel, T.; Hellweg, T. Molecules 2021, 26 , 3181.

(18) (a) Zhang, Q. M.; Xu, W.; Serpe, M. J. Angew. Chem. Int. Ed. 2014, 53, 4827. (b) Sorrell, C. D.; Carter, M. C. D.; Serpe, M. J. Adv. Funct. Mater. 2011, 21, 425.

(19) (a) Kleinschmidt, D.; Fernandes, M. S.; Mork, M.; Meyer, A. A.; Krischel, J.; Anakhov, M. V.; Gumerov, R. A.; Potemkin, I. I.; Rueping, M.; Pich, A. J. Colloid Interface Sci. 2020, 559, 76. (b) Kleinschmidt, D.; Nothdurft, K.; Anakhov, M. V.; Meyer, A. A.; Mork, M.; Gumerov, R. A.; Potemkin, I. I.; Richtering, W.; Pich, A. Mater. Adv. 2020, 1, 2983.

(20) (a) Begum, R.; Farooqi, Z. H.; Xiao, J.; Ahmed, E.; Sharif, A.; Irfan, A. J. Mol. Liq. 2021, 338, 116780. (b) Besold, D.; Risse, S.; Lu, Y.; Dzubiella, J.; Ballauff, M. Ind. Eng. Chem. Res. 2021, 60, 3922. (c) Roa, R.; Angioletti-Uberti, S.; Lu, Y.; Dzubiella, J.; Piazza, F.; Ballauff, M. Z. Phys. Chem. 2018, 232, 773. (d) Mei, Y.; Lu, Y.; Polzer, F.; Ballauff, M.; Drechsler, M. Chem. Mater. 2007, 19, 1062. (e) Lu, Y.; Proch, S.; Schrinner, M.; Drechsler, M.; Kempe, R.; Ballauff, M. J. Mater. Chem. 2009, 19, 3955.

(21) Wu, S.; Dzubiella, J.; Kaiser, J.; Drechsler, M.; Guo, X.; Ballauff, M.; Lu, Y. Angew. Chem. Int. Ed. 2012, 51, 2229.

(22) Angioletti-Uberti, S.; Lu, Y.; Ballauff, M.; Dzubiella, J. J. Phys. Chem. C 2015, 119, 15723.

(23) (a) Hoare, T.; Pelton, R. Macromolecules 2004, 37, 2544. (b) Hoare, T.; Pelton, R. Langmuir 2004, 20, 2123

(24) Sabadasch, V.; Wiehemeier, L.; Kottke, T.; Hellweg, T. Soft Matter 2020, 16, 5422.

(25) Brändel, T.; Sabadasch, V.; Hannappel, Y.; Hellweg, T. ACS Omega 2019, 4, 4636.

(26) Hoare, T.; McLean, D. J. Phys. Chem. B 2006, 110, 20327.

(27) Pelton, R. Adv. Colloid Interface Sci. 2000, 85, 1.

(28) Kroschwitz, J. I.; Kirk, R. E.; Othmer, D. F.; Seidel, A. Kirk-Othmer Encyclopedia of Chemical Technology; Wiley-Interscience: Hoboken, 2004.

(29) Hoshino, Y.; Imamura, K.; Yue, M.; Inoue, G.; Miura, Y. J. Am. Chem. Soc. 2012, 134, 18177.

(30) (a) Hoare, T.; Pelton, R. Curr. Opin. Colloid Interface Sci. 2008, 13, 413. (b) Kleinen, J.; Richtering, W. Colloid Polym. Sci. 2011, 289, 739.

(31) Friesen, S.; Hannappel, Y.; Kakorin, S.; Hellweg, T. Gels 2021, 7, 42.

(32) (a) Kratz, K.; Hellweg, T.; Eimer, W. Colloids Surf., A 2000, 170, 137. (b) Karanastasis, A. A.; Kenath, G. S.; Andersen, D.; Fokas, D.; Ryu, C. Y.; Ullal, C. K. J. Colloid Interface Sci. 2020, 568, 264.

(33) Wrede, O.; Reimann, Y.; Lülsdorf, S.; Emmrich, D.; Schneider, K.; Schmid, A. J.; Zauser, D.; Hannappel, Y.; Beyer, A.; Schweins, R.; Gölzhäuser, A.; Hellweg, T.; Sottmann, T. Sci. Rep. 2018, 13781. 
(34) (a) Gelissen, A. P. H.; Scotti, A.; Turnhoff, S. K.; Janssen, C.; Radulescu, A.; Pich, A.; Rudov, A. A.; Potemkin, I. I.; Richtering, W. Soft Matter 2018, 14, 4287. (b) Annegarn, M.; Dirksen, M.; Hellweg, T. Polymers 2021, 13, 827.

(35) Mourran, A.; Wu, Y.; Gumerov, R. A.; Rudov, A. A.; Potemkin, I. I.; Pich, A.; Möller, M. Langmuir 2016, 32, 723.
(36) Hirano, T.; Nakamura, K.; Kamikubo, T.; Ishii, S.; Tani, K.; Mori, T.; Sato, T. J. Polym. Sci., Part A: Polym. Chem. 2008, 46, 4575.

(37) Rasband, W. S. ImageJ, version 1.52a 2021; U. S. National Institutes of Health: Bethesda, 2021, https://imagej.nih.gov/ij/ (accessed April 3, 2022).

(38) Frisken, B. J. Appl. Opt. 2001, 40, 4087. 